\title{
Neuronal Activity-Regulated Gene Transcription in Synapse Development and Cognitive Function
}

\author{
Anne E. West ${ }^{1}$ and Michael E. Greenberg ${ }^{2}$ \\ ${ }^{1}$ Department of Neurobiology, Duke University Medical Center, Durham, North Carolina 27710 \\ ${ }^{2}$ Department of Neurobiology, Harvard Medical School, Boston, Massachusetts 02115 \\ Correspondence: michael_greenberg@hms.harvard.edu
}

Activity-dependent plasticity of vertebrate neurons allows the brain to respond to its environment. During brain development, both spontaneous and sensory-driven neural activity are essential for instructively guiding the process of synapse development. These effects of neuronal activity are transduced in part through the concerted regulation of a set of activitydependent transcription factors that coordinate a program of gene expression required for the formation and maturation of synapses. Here we review the cellular signaling networks that regulate the activity of transcription factors during brain development and discuss the functional roles of specific activity-regulated transcription factors in specific stages of synapse formation, refinement, and maturation. Interestingly, a number of neurodevelopmental disorders have been linked to abnormalities in activity-regulated transcriptional pathways, indicating that these signaling networks are critical for cognitive development and function.

$\mathrm{O}^{\prime}$ rganismal development is not the sole province of either nature or nurture; rather it is the interactions between genes and the environment that underlie the emergence of differentiated cells, tissues, and individuals. For the vertebrate brain, which continues its maturation long after birth, the interplay between genes and environment ensures that early sensory experiences have a significant influence over the way the brain is assembled and thus can functionally impact the way the mature brain works. Using sensory information to guide brain development is an adaptive way to accommodate behaviors to the environment into which the organism happens to have been born. However, having a flexible and prolonged period of postnatal development renders the vertebrate brain vulnerable to disruptions in the developmental program that can result in significant cognitive impairment. A substantial body of data indicates that sensory input in early life controls a program of gene expression that is essential for transducing sensory experience into long-lasting changes in brain development and function. Here we review evidence for the roles of these gene expression programs in both normal and aberrant brain development.

\section{Transcription in Activity-Regulated Brain Development}

The importance of sensory experience for brain development was elegantly demonstrated in the work of Hubel and Wiesel, who showed that

Editors: Morgan Sheng, Bernardo Sabatini, and Thomas C. Sudhof

Additional Perspectives on The Synapse available at www.cshperspectives.org

Copyright (C) 2011 Cold Spring Harbor Laboratory Press; all rights reserved; doi: 10.1101/cshperspect.a005744

Cite this article as Cold Spring Harb Perspect Biol 2011;3:a005744 
A.E. West et al.

vision shapes the synaptic organization of visual cortex during a critical period in postnatal life (Hubel 1982; Wiesel 1982). Although the gross arrangement of axonal projections from the two eyes into alternating ocular dominance columns in the visual cortex is present prior to eye opening (Crowley and Katz 2000), the boundaries of their synaptic target fields are highly dynamic and undergo refinement in the days and weeks after eye opening through a process that is sensitive to visual stimuli (Crair et al. 1998). Similar forms of activity-dependent changes in circuit wiring are found in brainstem nuclei and other sensory cortices (Foeller and Feldman 2004; Kandler 2004), and refinement of synaptic connections during development has also been observed in additional brain regions, including prefrontal cortex (Van den Heuvel and Pasterkamp 2008). These studies suggest that postnatal brain development is highly dependent on input from the environment, and they point toward synapse development as one of the key experience-dependent processes that impacts brain function.

The effects of sensory experience are manifested by the release of neurotransmitter at excitatory synapses where glutamate is the primary neurotransmitter. Glutamate released from the presynaptic terminal binds to its receptors on the postsynaptic neuron and triggers membrane depolarization of the postsynaptic neuron, leading to an activation of calcium channels followed by an influx of calcium into the cytoplasm. This increase in cytoplasmic calcium activates a program of gene expression in the nucleus (Greenberg et al. 1986; Sheng and Greenberg 1990; Corriveau et al. 1998; Lanahan and Worley 1998; Nedivi et al. 1998; Zhang et al. 2007). In addition to classic immediate-early genes (IEGs) such as Fos and Jun, which are regulated in many cell types by a broad variety of stimuli, the program of synaptic activityregulated gene transcription includes a large number of neuronally-enriched genes whose products are critical for aspects of synapse development and function. These include the surface membrane-associated protein CPG15, which regulates dendritic arbor formation (Nedivi et al. 1998), the extracellular pentraxin
Narp, which clusters AMPA-type glutamate receptors preferentially on GABAergic interneurons (O’Brien et al. 1999; Chang et al. 2010), and the scaffolding protein Homer, which links neurotransmitter receptors with intracellular signaling pathways (Xiao et al. 2000).

The fact that genes whose products modulate synapses are subject to activity-regulated transcription strongly suggests that transcriptional regulation is a mechanism by which synaptic activity can induce long-lasting changes at synapses. This hypothesis is supported by studies from the developing cortex, where, for example, visual experience induces gene expression during critical periods in early life (Majdan and Shatz 2006; Tropea et al. 2006). Among these gene products is Arc, which contributes to the regulated trafficking of AMPA-type glutamate receptors at synapses (Lyford et al. 1995; Tagawa et al. 2005; Tzingounis and Nicoll 2006). Neurons in the visual cortex of $A r c$ knockout $(\mathrm{KO})$ mice lack monocular deprivation-induced shifts in ocular dominance (McCurry et al. 2010). Furthermore, these neurons show neither depression of synaptic connections from the visually deprived eye, nor potentiation of inputs from the open eye. These data support the idea that neuronal activitydependent gene transcription is not only correlated with, but also directly required for, the experience-dependent synaptic changes that underlie the maturation of neural networks.

\section{MECHANISMS OF ACTIVITY-REGULATED TRANSCRIPTION}

The first evidence that extracellular signals rapidly induce gene transcription came from studies of quiescent fibroblasts, which were shown to rapidly and robustly up-regulate transcription of the IEG Fos when exposed to growth factors (Greenberg and Ziff 1984). The importance of stimulus-dependent regulation of IEG transcription in neuronal cells was first suggested by the observation that nerve growth factor and epidermal growth factor induce Fos transcription in the neuroendocrine cell line PC12 (Greenberg et al. 1985). Subsequent studies revealed that activation of nicotinic acetylcholine 
or glutamate receptors leads to membrane depolarization and an opening of L-type voltagesensitive calcium channels (L-VSCCs) thus triggering Fos transcription (Greenberg et al. 1986; Morgan and Curran 1986). These initial findings set the stage for a plethora of subsequent studies, which have established that calcium-signaling pathways are of central importance for synaptic activity-regulated transcription in neurons (Ghosh and Greenberg 1995). The up-regulation of Fos and other IEGs has been demonstrated in neurons in vivo following seizure, sensory stimulation, and a wide range of other physiologically relevant stimuli that evoke changes in neuronal firing (Hunt et al. 1987; Morgan et al. 1987; Graybiel et al. 1990; Sherin et al. 1996; Herdegen and Leah 1998; Barth et al. 2004; Velho et al. 2005).

\section{Synapse to Nucleus Calcium Signaling}

At synapses in the central nervous system (CNS), neurotransmitter reception triggers calcium influx across the plasma membrane through a number of ligand- and voltage-gated calcium channels (Sabatini et al. 2001). Intracellular calcium increases can also be induced by the release of calcium from intracellular stores, although the role of these channels in regulating neuronal transcription is not well understood (Berridge 1998). The route of calcium entry significantly influences the transcriptional consequence of a given calcium signal. For example, although calcium entering through both NMDA-type glutamate receptors (NMDA-Rs) and L-VSCCs can modulate synaptic activity-dependent gene transcription in neurons (Cole et al. 1989; Murphy et al. 1991), the source of synaptic activity and calcium entry leads to the activation of distinct intracellular signaling and transcription factor pathways (Bading et al. 1993; Lerea and McNamara 1993).

The level of free calcium in a cell is regulated by hundreds of calcium-binding proteins that are present within neurons (Clapham 2007). The differential localization of these calcium buffers and effectors near the sources of calcium entry may provide an explanation for how distinct intracellular signaling pathways can be activated depending on the route of calcium entry into a neuron (Deisseroth et al. 1996; Dolmetsch et al. 2001; Hardingham et al. 2001). However, in addition to cytoplasmic calcium, an elevation of nuclear calcium is required for the expression of a significant subset of activity-regulated genes, implicating local nuclear calcium effectors as well as synaptic calcium signaling proteins in this process (Dolmetsch 2003; Zhang et al. 2009). Whether signaling proteins locally activated at synapses translocate to the nucleus to regulate their targets (Meffert et al. 2003; Jordan et al. 2007), and/or whether action potentials or calcium waves carry the signal from synapse to nucleus (Adams and Dudek 2005), remains an area of active investigation. Overall, the net effect of these actions of calcium in multiple cellular compartments is to provide a robust yet selective link between synaptic stimuli and the gene transcription response.

\section{Molecular Mechanisms of Activity-Regulated Transcription}

Activity-dependent signaling pathways regulate gene transcription by modifying the function, localization, or expression of transcriptional regulators in the nucleus (West et al. 2002). In rare cases, calcium may bind directly to a transcription factor, altering its conformation and function (Carrion et al. 1999). More commonly, calcium bound to calmodulin or other calcium sensors activates any of a number of calciumregulated intracellular signaling cascades, which include kinases of the calcium-calmodulin kinase (CaMK) and Ras/mitogen-activated protein kinase (MAPK) signaling pathways as well as the calcium-regulated phosphatase calcineurin (Bading and Greenberg 1991; Rosen et al. 1994; Deisseroth et al. 2003; Burgoyne 2007; Wayman et al. 2008b). Changes in the activity of these signaling intermediates subsequently alter posttranslational modifications on transcription factors and transcriptional coregulators (Greer and Greenberg 2008).

The most rapid activity-dependent changes in transcription are mediated by nuclear transcription factors that sit prebound and primed 
A.E. West et al.

at their target gene promoters (Kim et al. 2010). Stimulus-induced posttranslational modifications of these transcription factors induce dynamic changes in protein-protein interactions that rapidly recruit RNA polymerase (Chrivia et al. 1993; Shalizi et al. 2006). A second and slower wave of stimulus-dependent transcription is mediated by factors that translocate to the nucleus following stimulation (Hogan et al. 2003; Shrum et al. 2009). These factors may require the recruitment of chromatin-modifying enzymes to their target gene promoters prior to making these genes competent for stimulus-regulated transcription (Hargreaves et al. 2009). Finally, a late wave of gene transcription is mediated by induced expression of immediate-early gene transcription factors that are targets of regulation by the rapidly modified factors (Sheng and Greenberg 1990). Complexes of these transcription factors regulate transcription of late response genes in a cell type and stimulus-specific manner depending on their differential recruitment to distinct sets of gene promoters (Hill and Treisman 1999).

In addition to the activity-dependent regulation of sequence-specific DNA-binding proteins, a growing body of evidence suggests that changes in chromatin structure play an important role in shaping the transcriptional response to neuronal activity (Crosio et al. 2000; Kumar et al. 2005; Qiu and Ghosh 2008; Ma et al. 2009; Kim et al. 2010). The basic repeating unit of chromatin is the nucleosome, which is comprised of 147bp of genomic DNA wrapped around an octamer of histone proteins (two copies each of histones $\mathrm{H} 2 \mathrm{~A}, \mathrm{H} 2 \mathrm{~B}, \mathrm{H} 3$, and H4). By modulating nucleosome position or higher-order chromatin structures, signaling pathways can change the accessibility of transcriptional regulatory elements to DNA-binding proteins, thus altering transcriptional output.

Both genomic DNA and histone proteins are targets of posttranslational modifications that can be regulated by activity-dependent signaling pathways. In mammals, genomic DNA is subject to methylation at $\mathrm{CpG}$ dinucleotides throughout both expressed and nonexpressed regions of the genome (Klose and Bird 2006). Although the specific mechanisms of DNA demethylation remain controversial, a recent study describes a rapid reduction in methylation of genomic DNA at the Bdnf and Fgfl loci in postmitotic hippocampal neurons following electroconvulsive seizure, raising the possibility that DNA demethylation may contribute to transcriptional induction of these genes (Ma et al. 2009). A larger body of data implicates histone modifications in the stimulus-dependent regulation of transcription. Histones are subject to multiple posttranslational modifications (e.g., acetylation, methylation, phosphorylation) at specific residues within their flexible amino-terminal tail domains (Strahl and Allis 2000). Many of the enzymes that mediate these modifications are targets of regulation by activity-dependent signaling cascades, and in particular, increases in histone acetylation are highly correlated with transcriptional activation (Tsankova et al. 2004; Roh et al. 2005; Bernstein et al. 2007; Guan et al. 2009). Finally, neuronal activity may also regulate chromatin by modulating ATP-dependent chromatin remodeling complexes, which use the energy from ATP hydrolysis to induce nucleosome sliding, thus revealing or masking transcription factor binding sites. Regulated expression of a neural specific member of the BRG1/BRM family of chromatin remodeling factors (BAF53b) has been implicated in orchestrating the developmental changes in gene expression programs that underlie neurogenesis and dendrite outgrowth (Wu et al. 2007; Yoo et al. 2009). In addition, BRG1 has been shown to contribute to activity-dependent gene transcription through its interactions with the calcium regulated transcriptional coactivator CREST (Qiu and Ghosh 2008).

The Fos gene provides a useful model for understanding how the integration of these multiple activity-regulated transcriptional mechanisms at a single promoter may permit the very rapid and robust activity-dependent induction of transcription in neurons (Fig. 1). Even in the absence of neuronal activity, Fos is poised for activation. In quiescent cells, the Fos promoter is bound by the activity-regulated transcription factors CREB and SRF, histones that bear a transcriptionally permissive posttranslation 

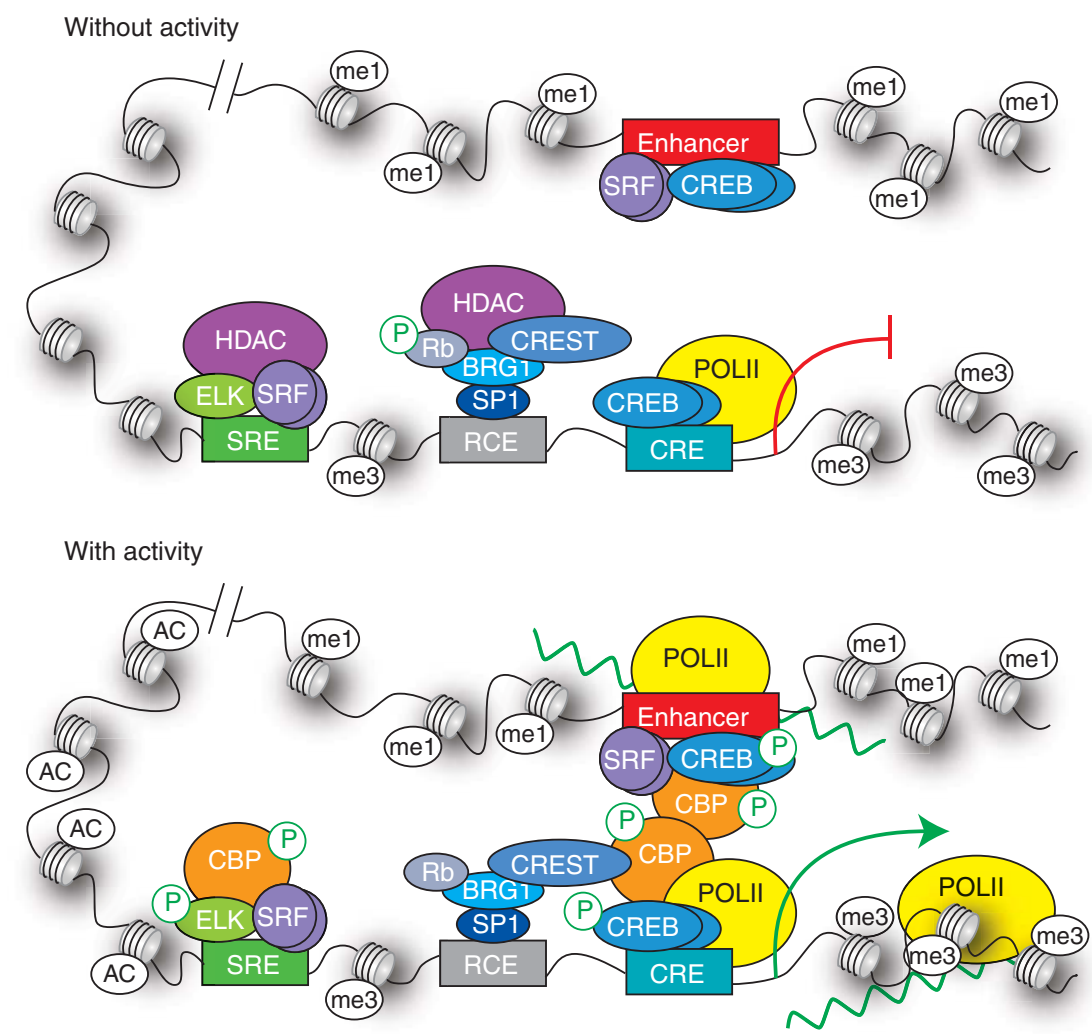

Figure 1. Mechanisms that regulate activity-dependent transcription of Fos. The top panel represents Fos in the absence of activity and the bottom panel shows Fos following a synaptic stimulus that activates intracellular calcium $\left(\mathrm{Ca}^{2+}\right)$ signaling. In the absence of activity, Fos is primed for activation by the association of the transcriptional activators CREB with the cAMP/calcium response element (CRE) and Elk-1/SRF with the serum response element (SRE). The promoter is also bound by RNA polymerase II (POLII), and has the presence of histone $\mathrm{H} 3$ lysine 4 trimethylation (me3) at promoter histones. However, the gene is held in a repressed state by the presence of histone deacetylases (HDACs) recruited to Elk-1 and the Retinoblastoma (Rb)-BRG1-CREST complex, which binds the zinc-finger transcription factor Sp1 at the Retinoblastoma control element (RCE). Following activation of calcium-dependent signaling pathways, the histone acetyltransferase CBP is recruited to phosphorylated (P) CREB, inducing local histone acetylation (AC). Calcineurin-dependent dephosphorylation of Rb releases the HDACs, which are then exported from the nucleus in a phosphorylation-dependent manner. RNA polymerase II and CBP are also recruited to histone H3 lysine 4 monomethylated (me1) enhancer regions that are prebound by SRF and CREB and hypothesized to interact with the Fos promoter through longdistance looping. Transcription of Fos mRNA and of eRNAs is then induced (green wavy lines).

modification (histone $\mathrm{H} 3$ lysine 4 trimethylation), and the RNA polymerase II complex (Kim et al. 2010). However, the promoter is held in a repressed state as reflected by the deacetylation of promoter histones, which depends at least in part on the presence of histone deacetylases (HDACs) recruited by the Rb-BRG1-CREST corepressor complex (Qiu and Ghosh 2008). In addition, intragenic polymerase pause sites have been identified in the Fos gene that may provide an additional regulatory step for the production of fully elongated Fos transcripts (Lamb et al. 1990; Ryser et al. 2007). Following synaptic activity, multiple calcium-regulated signaling events impact proteins at the Fos promoter to relieve this repression. These include (1) the phosphorylation of CREB at Ser133, which facilitates 
A.E. West et al.

recruitment of the histone acetyltransferase CBP to the Fos promoter (Sheng et al. 1991; Chrivia et al. 1993); (2) the MAP kinase dependent phosphorylation of Elk-1, which allows Elk to acts as a cofactor for SRF-dependent transcription of Fos (Marais et al. 1993; Xia et al. 1996); (3) the calcineurin-dependent dephosphorylation of $\mathrm{Rb}$, which releases HDACs from the BRG1-CREST complex (Qiu and Ghosh 2008); and (4) the phosphorylation of the HDACs, which leads to their nuclear export (Chawla et al. 2003). Furthermore, in addition to these local events at the Fos promoter, membrane depolarization induces widespread recruitment of CBP and RNA polymerase II to enhancer elements that neighbor Fos and other activity-regulated genes (Kim et al. 2010). Similar to promoter regulatory elements, many of these enhancer elements are prebound by activity-regulated transcription factors including SRF, CREB, and MEF2, which may act to recruit CBP (Flavell et al. 2008; Kim et al. 2010). Activity-dependent RNA polymerase II recruitment to enhancers is associated with the induced expression of short noncoding enhancer RNAs (eRNAs) (Kim et al. 2010). Although the functions of eRNAs are not known, they may play a role in recruiting chromatin-modifying enzymes that maintain the chromatin landscape near activity-induced genes in a transcriptionally permissive state.

\section{TRANSCRIPTIONAL CONTRIBUTIONS TO SYNAPSE DEVELOPMENT}

Investigation of the mechanisms that mediate activity-dependent transcription of neuronal genes has led to the identification of important transcription factor targets of calcium-signaling pathways that regulate synapse development. The contributions of activity-regulated gene transcription to synapse formation have been demonstrated by disrupting the function and/ or modulation of specific transcription factors using a variety of genetic techniques. Here we review this literature and summarize the important contributions of some of the best-studied transcription factors in distinct stages of synapse development.
Synapse development can be divided into roughly four epochs (Fig. 2). First, axons have to find their target cells, and dendrites need to be elaborated to provide target fields for synapse formation. Next, contact between axons and dendrites initiates a period of exuberant synapse formation. This is followed by a period of synapse elimination that refines the accuracy of circuit wiring patterns. Finally, the functional balance between excitatory and inhibitory transmission is modulated through regulation of both synapse number and function. Neuronal activity plays an instructional role at each of these stages, and specific functions of several calcium-regulated transcriptional pathways in each phase of synapse development have been elucidated.

\section{Neurite Outgrowth}

Prior to synaptogenesis, spontaneous electrical activity and electrical coupling of neurons drive intracellular calcium ion fluctuations that modulate transcriptional programs and neural development (Spitzer 2006). These calcium transients contribute to key aspects of neuronal differentiation, including neurotransmitter phenotype (Borodinsky et al. 2004), neuronal migration (Kokobu et al. 2009), axon pathfinding (Hanson and Landmesser 2004), dendrite outgrowth (Rajan and Cline 1998), and synapse maturation (Hooks and Chen 2006).

Activation of intracellular calcium signaling pathways promotes axonal and dendritic outgrowth, bringing pre- and postsynaptic partner neurons into apposition (Cline 2001; Henley and Poo 2004). Pharmacological and/or genetic inactivation of any one of several calcium-regulated phosphatases, kinases, and transcription factors can interfere with the growth-promoting effects of calcium, suggesting that multiple signaling pathways and transcription factors may contribute to different aspects of activitydependent neurite outgrowth (Polleux et al. 2007). For example NFAT-dependent transcription is regulated by the calcium-dependent phosphastase calcineurin, which promotes translocation of NFAT from the cytoplasm to the nucleus (Hogan et al. 2003). Triple Nfatc2/3/4 


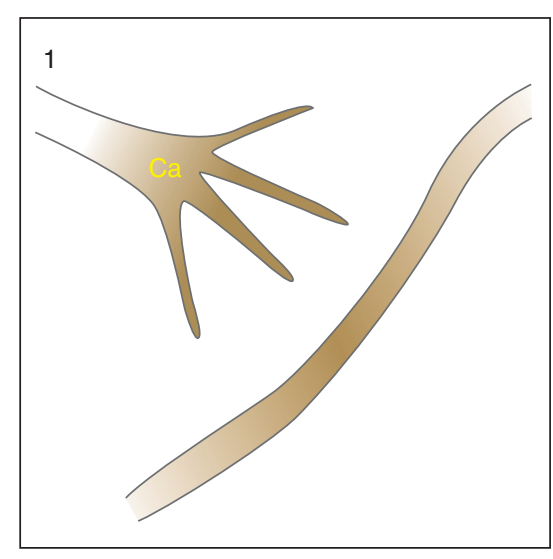

Neurite outgrowth

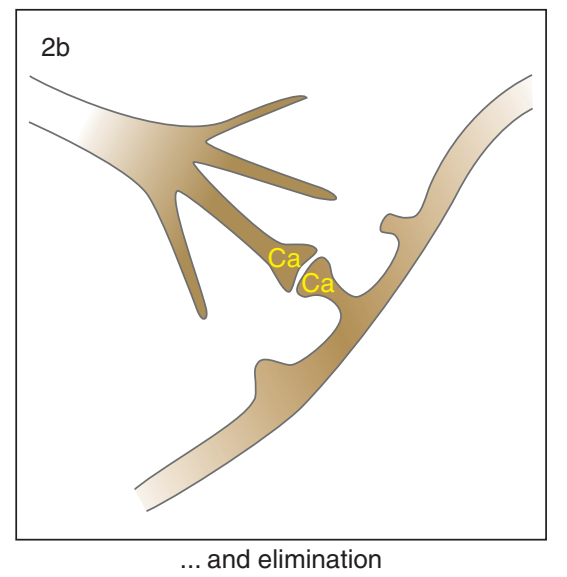

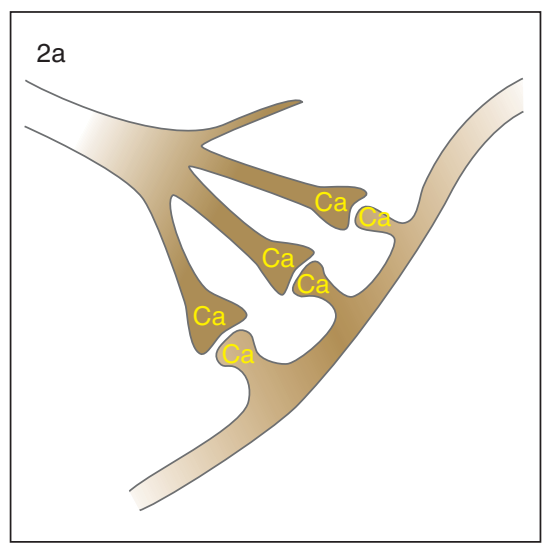

Synapse formation..

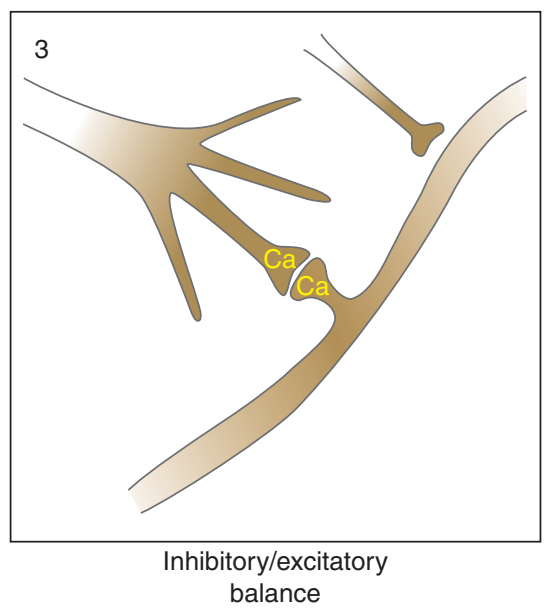

Figure 2. Activity-dependent transcription factor regulation of distinct stages in synapse development. Neurite outgrowth promotes contacts between axons (left) and dendrites (right) that define potential synaptic target fields. At some of these points of contact, actin-rich dendritic spines develop at sites opposed to axon terminals to form excitatory synapses. These synapses either stabilize and strengthen, or they are eliminated. Finally, excitatory synapses are balanced by the formation of inhibitory synapses ( pictured on the dendritic shaft). Calcium signaling $(\mathrm{Ca})$ is involved at each of these steps.

KO mice show severe axon pathfinding defects in vivo and fail to display BDNF-dependent neurite outgrowth in vitro (Graef et al. 2003). Other calcium-regulated transcription factors appear to have a more selective effect on dendrite outgrowth. In cerebellar granule neurons CaMKIIdependent regulation of NeuroD selectively specifies dendritic morphogenesis while having no effect on axon outgrowth (Gaudilliere et al. 2004). Dendrite development is also impaired by mutations of the calcium-regulated transcriptional coactivator CREST (Aizawa et al. 2004) and the neural-specific BRG-family chromatin remodeling protein BAF53b (Wu et al. 2007).

At the transcriptional level, calciumregulated pathways cooperate with activityindependent tyrosine kinase signaling pathways to integrate intrinsic and experience-guided stages of development (Takasu et al. 2002; Pfeiffenberger et al. 2005). As a transcription factor that integrates the activation of multiple signaling cascades, including calcium signaling pathways, receptor tyrosine kinases, and G-protein coupled receptors, SRF is particularly well 
A.E. West et al.

poised to contribute to early neural development (Knoll and Nordheim 2009). Loss-offunction studies show that SRF is essential for the regulation of neurite outgrowth. Srfdeficient neurons have abnormal growth cones and fail to show growth cone collapse responses to axon guidance cues including ephrins and semaphorins (Knoll et al. 2006). Mice lacking Srf in the developing nervous system show impairments of several actin-dependent processes including neural migration, neurite outgrowth, and axon pathfinding (Alberti et al. 2005; Knoll et al. 2006; Wickramasinghe et al. 2008). The growth cone defects of Srf knockout neurons are mimicked by overexpression of a dominant-interfering form of the G-actin regulated SRF cofactor Mal (Knoll et al. 2006). These data suggest that SRF is part of an actinregulated feedback loop for the modulation of neuronal morphology during the earliest steps of axon outgrowth and neuritogenesis.

\section{Synapse Formation and Maturation}

Upon reaching their target fields, axons arborize and dendrites branch, increasing the likelihood of cell-cell contact. Many of these contacts are transient; however, a small number become stable adhesive junctions that mature into synapses (Niell et al. 2004). Stabilization of nascent synapses promotes the growth of local dendritic branches, iteratively linking synaptogenesis with dendritic arbor elaboration (Cline and Haas 2008).

Calcium signaling pathways play an important role in coordinating both the local and the cell-wide processes that mediate this stage of synapse formation. Local calcium transients in both dendritic and axonal filopodia are correlated with reduced mobility, which may allow for stabilization of contact sites (Gomez et al. 2001; Lohmann and Bonhoeffer 2008). Cotemporaneous activation of calcium-regulated transcription factors triggers the induction of gene expression programs that promote dendrite growth and synaptic maturation (Redmond and Ghosh 2005). Interestingly, the two transcription factors implicated at this stage in synapse formation, NFAT and CREB, have opposite effects on synapse number, suggesting that striking a balance between these pathways may be important for proper synaptogenesis.

To study the cell-autonomous role of postsynaptic NFAT activity in synapse formation, Schwartz and colleagues transfected Xenopus optic tectal neurons with either a genetically encoded calcineurin inhibitor or the peptide $\mathrm{N}$ VIVIT, which is a nuclear localized peptide that blocks the association of calcineurin with its targets including NFAT (Schwartz et al. 2009). Transfected neurons showed increased dendritic branching and had an increased number of miniature excitatory postsynaptic potentials (mEPSPs), suggesting that activation of NFAT normally serves to limit both dendrite arborization and synapse formation. By contrast, CREB activity is positively coupled to excitatory synapse formation. In hippocampal neurons, activation of CaMKI or CaMKIV-dependent phosphorylation of CREB is required for the ability of membrane depolarization or NMDAreceptor activation to promote dendritic arborization (Redmond et al. 2002; Wayman et al. 2006, 2008a). Furthermore, CREB activity drives the formation and enlargement of dendritic spines, which are actin-rich protrusions of dendrites that are the sites of excitatory synapse formation onto many CNS neurons (Murphy and Segal 1997; Marie et al. 2005; Suzuki et al. 2007). One gene target of CREB that may promote spine development is the microRNA miR132, which positively regulates dendritic spine formation through its ability to modulate activity of the p250GAP-Rac1-Pak signaling cascade (Impey et al. 2010). These data suggest that calcium-regulated transcription factors coordinate synaptogenesis by coregulating both dendrite development and synaptic maturation.

\section{Activity-Dependent Excitatory Synapse Elimination}

The sheer exuberance of synapse growth during brain development presents a challenge to the specificity of neural circuit construction. In vivo, synaptic density reaches its peak very early in postnatal life, long before brain development 
is complete (Rakic et al. 1986). A key step in the refinement of synaptic connections during late stages of postnatal brain patterning is mediated by the activity-dependent elimination of synapses (Purves and Lichtman 1980).

Synapse elimination has been particularly well studied at the neuromuscular junction $(\mathrm{NMJ})$, as the accessibility of these synapses to both visualization and cell type-specific genetic manipulation has facilitated molecular understanding of the elimination process (Sanes and Lichtman 2001). Initially, multiple motor neurons innervate a single muscle fiber. However, during postnatal development all but one of the motor axons lose their synapses and retract from the muscle while synapses from the single remaining axon become stronger and larger. Inhibiting neurotransmitter synthesis in the presynaptic motor neurons prevents elimination, suggesting that it is actively mediated by neurotransmission (Misgeld et al. 2002). In the brain, a similar developmental transition from multiple weak inputs to a single strong input occurs in the cerebellum for climbing fiber innervation of Purkinje cells (Rabacchi et al. 1992) and for retinal ganglion cell (RGC) innervation of neurons in the lateral geniculate nucleus (LGN) of the thalamus (Chen and Regehr 2000). At the RGC-LGN synapse, synapse elimination is initiated by spontaneous activity of the RGC neurons, whereas later stages of synapse strengthening and maintenance require sensory-driven synaptic activity (Hooks and Chen 2006). Further understanding of the molecular processes underlying the stages of synapse development may help to explain the differential role of these forms of neural activity in the refinement of synaptic connections.

Possible insight into the molecular mechanisms by which activity-dependent transcription factors may regulate synapse elimination has emerged from studies on the role of MEF2. In hippocampal neurons, genetic manipulations that decrease MEF2 expression are associated with increased numbers of glutamatergic synapses (Flavell et al. 2006; Barbosa et al. 2008), whereas conditional overexpression of a constitutively active MEF2-VP16 fusion protein is sufficient to acutely reduce excitatory synapse number (Flavell et al. 2006). Furthermore, in granule neurons of the cerebellum, MEF2-dependent transcription negatively regulates differentiation of specialized postsynaptic structures termed dendritic claws (Shalizi et al. 2006). The ability of MEF2 to regulate synapse number in both of these neuronal types is dependent on calcium signaling pathways, suggesting that MEF2 may participate in a negative feedback loop that links synaptic activity with the control of excitatory synapse number. A genome-level analysis of the MEF2-dependent transcriptional program in hippocampal neurons identified hundreds of activity-dependent MEF2 target genes that contribute to a variety of different aspects of synaptic function (Flavell et al. 2008). Among these targets, Arc (Chowdhury et al. 2006) and Homerl stand out for their roles in regulating synaptic AMPA-type glutamate receptor content (Sala et al. 2003). Another MEF2 target gene, Bdnf, not only modulates the strength of both excitatory and inhibitory synapses (Poo 2001) but is also tightly linked to control of GABAergic synapse numbers (Huang et al. 1999; Hong et al. 2008). These data suggest that by coordinating the expression of a broad program of gene expression, MEF2 may regulate multiple processes at synapses that act in concert to restrict excitatory synaptic transmission.

\section{Inhibition/Excitation Balance}

In vivo, neuronal firing depends not only the strength of excitatory inputs but also on the number, location, and strength of inhibitory inputs (Mann and Paulsen 2007). The development of inhibitory synapses is sensitive to sensory experience (Morales et al. 2002), and the functional maturation of local inhibitory connections in the cortex is thought to trigger closure of the critical period of cortical plasticity (Hensch 2005). Disruption of excitatory/ inhibitory balance has been associated with several developmental neuropsychiatric disorders including autism, schizophrenia, and Rett Syndrome (Rubenstein and Merzenich 2003; Levitt et al. 2004; Dani et al. 2005). 
A.E. West et al.

One transcription factor that plays a role in inhibitory/excitatory synapse balance is Npas4. Expression of Npas4 is robustly induced by the activation of calcium signaling pathways following membrane depolarization or synaptic NMDA-type glutamate receptor activation in vitro, and following sensory stimuli in vivo (Lin et al. 2008; Zhang et al. 2009). Acute RNAimediated knockdown of Npas4 during synaptogenesis in cultured hippocampal neurons reduces GABAergic synapse numbers while overexpression of Npas4 selectively increases GABAergic synapses (Lin et al. 2008). By contrast these manipulations have no effect on the number of glutamatergic synapses, indicating a selective role for Npas4 in regulating GABAergic synapse development. Within intact circuits, homeostatic plasticity mechanisms compensate for changes in inhibition by inducing compensatory changes in the number or strength of excitatory synapses (Turrigiano and Nelson 2004). Consistent with role for Npas4 in regulation of this excitatory/inhibitory balance, manipulating Npas4 expression in a single pyramidal neuron within an organotypic hippocampal slice preparation induces a compensatory change in the number and/or strength of the excitatory connections onto the transfected cell that oppose the change in GABAergic synapse number (Lin et al. 2008). Overall these data indicate that activity-induced Npas4 expression acts to increase inhibition, and suggest that one important function of Npas4 is to maintain the excitation/inhibition balance in the face of changing patterns of neural activity.

Over 270 unique genes are differentially regulated by knockdown of Npas4, and a large percentage of these are also activity-regulated transcripts, including the gene encoding the neurotrophin BDNF (Lin et al. 2008). The identification of $B d n f$ as an Npas4 target is of particular interest because expression of BDNF has been tightly associated with GABAergic synapse formation (Huang et al. 1999; Kohara et al. 2007; Sakata et al. 2009). Consistent with the idea that activity-dependent regulation of $B d n f$ is important for its effects on inhibition, mutation of the CREB-binding site in Bdnf promoter IV selectively eliminates the activity-inducible component of $B d n f$ exon IV expression, yet still results in significantly reduced GABAergic synapse numbers (Hong et al. 2008). Notably, the transcription factor CaRF is another of the transcriptional regulators that contributes to $B d n f$ exon IV expression (Tao et al. 2002), and knockout of this factor is also associated with selective alterations in GABAergic but not glutamatergic synapse development (McDowell et al. 2010). Taken together these data suggest that regulation of $B d n f$ may be a common mechanism for transcriptional control of GABAergic synapse numbers.

\section{ACTIVITY-REGULATED TRANSCRIPTION IN COGNITIVE DISORDERS}

A subset of cognitive disorders is characterized by symptoms that first appear during early postnatal life. These include nonsyndromic forms of mental retardation, Down syndrome, Fragile- $\mathrm{X}$ syndrome, Angelman syndrome, Duchene muscular dystrophy, autism spectrum disorders, Rett syndrome, and other rare genetic diseases (Volpe 2008). At the time of birth, neurogenesis is largely complete and most axons have reached their target destinations. However, synapse formation and elimination, as well as glial proliferation and differentiation, are still ongoing and thus represent strong candidate processes to contribute to the pathogenesis of these disorders. Consistent with the evidence that activity-regulated transcriptional pathways contribute to postnatal synapse development, advances in human genetics have revealed that a subset of these disorders are caused by mutations in sequence-specific DNA-binding transcription factors, transcriptional cofactors, or the signaling pathway components that couple transcription to synaptic activity (Hong et al. 2005).

\section{Rett Syndrome}

Rett Syndrome (RTT; OMIM 312750) is a severe neurodevelopmental disorder that occurs almost exclusively in females. RTT is characterized by arrested development that is clinically apparent by 6 to 18 months of age, regression 
of acquired skills, loss of speech, stereotypical hand wringing movements, microcephaly, seizures, and mental retardation (Bienvenu and Chelly 2006; Chahrour and Zoghbi 2007). More than $90 \%$ of clinically diagnosed cases of RTT are caused by loss-of-function mutations in the $\mathrm{X}$-chromosome gene encoding Methyl-CpG binding protein 2 (MECP2) (Amir et al. 1999).

MeCP2 is an abundant, nuclear methylDNA-binding protein that regulates transcription by recruiting chromatin-modifying enzymes onto methylated regions of genomic DNA (Boyes and Bird 1991; Nan et al. 1998; Fuks et al. 2003; Kimura and Shiota 2003). Despite the general nature of MeCP2's DNAbinding activity and its broad tissue distribution, the deleterious effects of MECP2 mutations in RTT are largely limited to the nervous system (Chahrour and Zoghbi 2007). MeCP2 expression is significantly higher in neurons than in other cell types, and loss of MeCP2 has selective effects on neuronal chromatin. Specifically, deficiency of MeCP2 in neurons is associated with genome-wide elevation of acetylated histone $\mathrm{H} 3$ and increased expression of histone H1 (Skene et al. 2010). Unlike the other histones, which are incorporated into nucleosomes, histone $\mathrm{H} 1$ binds to the linker DNA between nucleosomes and is thought to play a role in stabilizing the structure of chromatin fibers (Wolffe et al. 1997). If the enhanced expression of histone $\mathrm{H} 1$ in Mecp2 null neurons is compensatory, this could imply that MeCP2 has a similar structural role. Nonetheless, these global chromatin changes in Mecp2 null neurons are associated with surprisingly subtle, and potentially selective, changes in gene expression (Tudor et al. 2002; Chahrour et al. 2008; Skene et al. 2010). It is possible that even a subtle change in the amplitude or timing of gene expression in Mecp2 mutant neurons is sufficient to disrupt functionally important and normally tightly regulated neuronal processes. One potential target of MeCP2 is BDNF. Both transcription of $B d n f$ mRNA and the secretion of BDNF protein are dysregulated in Mecp2 null mice (Chen et al. 2003; Wang et al. 2006). Regardless of whether these changes in BDNF expression are causative for RTT, enhancing BDNF expression ameliorates some of the synaptic, locomotor, and respiratory symptoms in Mecp 2 mutant mice, suggesting potential for the development of future RTT therapies targeting this growth factor (Chang et al. 2006; Ogier et al. 2007; Kline et al. 2010).

Several lines of evidence suggest that defects in both synapse development and function are involved in the pathophysiology of RTT. The onset of RTT symptoms during postnatal life coincides with the peak of synapse formation (Chahrour and Zoghbi 2007). Consistent with the hypothesis that RTT arises as a disorder of development, autopsy studies have found reduced dendritic branching and increased cell packing density in RTT brains, in the absence of evidence for neurodegeneration or inflammation (Armstrong 2005). The functions of $\mathrm{MeCP} 2$ in synapse development have been addressed experimentally in Mecp2 loss-offunction mouse models. Among the excitatory synaptic defects that have been detected are reductions in dendritic spine density (Belichenko et al. 2009; Tropea et al. 2009), decreased glutamatergic synapse numbers (Chao et al. 2007), decreased presynaptic glutamatergic vesicle release (Nelson et al. 2006), and reduced excitatory synaptic amplitudes (Chao et al. 2007; Dani and Nelson 2009; Tropea et al. 2009; Wood et al. 2009). Changes in the strength and/or number of GABAergic synapses have also been observed (Medrihan et al. 2008; Deng et al. 2010; Zhang et al. 2010). Although long-term potentiation and depression (LTP and LTD, respectively) can be induced in slices from Mecp2 mutant animals (Dani and Nelson 2009), other forms of circuit plasticity are altered in the mutant mice in vivo. For example, acute monocular deprivation induces an ocular dominance shift in adult female Mecp2 heterozygous mice long after brain maturation has closed the critical period for this form of plasticity in their wild-type littermates (Tropea et al. 2009). Interestingly, MeCP2 is rapidly phosphorylated at Ser421 in response to synaptic activity in vivo, and NMDA-receptor activation or membrane depolarization in vitro, suggesting a potential mechanism through which the 
A.E. West et al.

function of MeCP2 may be directly regulated by neural activity (Zhou et al. 2006). These data raise the possibility that loss of Mecp2 may impair the normal activity-dependent process of synapse maturation, trapping the brain in an immature state. An important corollary of these findings is the possibility that uncovering strategies to reawaken brain maturation could offer prospective therapies to treat the debilitating symptoms of RTT.

\section{Angelman Syndrome}

Angelman syndrome (AS; OMIM 105830) is a developmental disorder characterized by mental retardation, movement or balance disturbances, characteristic abnormal behaviors, and severe limitations in speech and language. Most cases are caused by maternally inherited deletions of the imprinted region on chromosome 15q11-q13, whereas paternal deletion of the same chromosomal region causes the clinically distinct Prader-Willi Syndrome (Jiang et al. 1998a). The key maternally expressed gene within this region is Ube $3 a$, and failure to inherit a functional maternal Ube3a accounts for $85 \%-95 \%$ of AS cases (Matsuura et al. 1997).

Targeted genetic inactivation of Ube3a in mice recapitulates many of the neurological symptoms of AS, offering a model system to investigate the pathophysiology of this disorder (Jiang et al. 1998b). Mice that inherit mutant Ube3a through the maternal lineage show impaired motor function, audiogenic seizures, and reduced context-dependent learning (Jiang et al. 1998b). During very early postnatal development of the visual cortex, glutamatergic transmission is normal in Ube3a mutant mice (Yashiro et al. 2009). However after eye opening, wild type mice show a visual stimulus-dependent increase in the number of functional glutamatergic connections, whereas this change is absent in maternally deficient Ube3a mice (Yashiro et al. 2009). Moreover, these mice fail to show rapid ocular dominance column plasticity upon monocular deprivation (Sato and Stryker 2010). These observations suggest that activity-dependent mechanisms of glutamatergic synaptic plasticity may be abnormal in Ube3a mutant mice. Consistent with this hypothesis, maternally deficient Ube3a mice show impairments in both LTP and LTD relative to their wild-type littermates in slice preparations from cortex and hippocampus (Jiang et al. 1998b; Yashiro et al. 2009).

Ube3a is a member of the E3 family of ubiquitin ligases, which direct the addition of ubiquitin to specific target proteins, often resulting in their degradation (Yi and Ehlers 2005). Imprinting of Ube3a is restricted to neurons, suggesting that the neurological selectivity of symptoms in AS may arise from abnormal turnover of neuronal proteins (Dindot et al. 2008). One target of Ube3a-dependent regulation that may contribute to the synaptic plasticity defects in Ube3a mutant mice is the AMPA-type glutamate receptor trafficking protein Arc (Greer et al. 2010). Ube3a binds and ubiquitinates Arc, and in the hippocampus of Ube3amutant mice, following kainate-induced seizure Arc protein levels are elevated relative to wildtype controls. Previous studies have shown that reducing Arc expression increases the surface expression of AMPA-type glutamate receptors whereas increasing Arc expression drives AMPA receptor endocytosis (Chowdhury et al. 2006; Rial Verde et al. 2006; Shepherd et al. 2006). Surface synaptic GluA1 expression is reduced in Ube3a-deficient neurons, and overexpression of Ube3a rescues the synaptic defects in a manner that requires its ubiquitin ligase domain (Greer et al. 2010). Synaptic GluA1 expression can be rescued in Ube3a-deficient neurons by RNAi-mediated knockdown of Arc. Interestingly, excitatory synaptic defects fail to appear in visual cortical slices made from Ube3a mutant mice reared in the dark a condition under which Arc levels would be expected to be low in both wild-type and Ube3a-deficient mice. By contrast, deficiencies in synaptic plasticity are rapidly induced in these Ube3a-mutant mice following a short period of light exposure that may trigger abnormally high levels of Arc induction in the absence of Ube3a (Yashiro et al. 2009). Arc transcription is robustly induced by neural activity, but notably expression of Ube3a is also induced by 
membrane depolarization in a MEF2-dependent manner (Greer et al. 2010), facilitating increased Ube $3 a$-mediated Arc protein degradation and thus fine-tuning the level of Arc protein. These data raise the possibility that finely tuned regulation of Arc protein levels is essential for activity-dependent synapse maturation, and that dysregulation of activity-dependent synaptic protein expression may contribute to neurodevelopmental abnormalities in AS (Fig. 3).

\section{Autism}

Autism spectrum disorders (ASD; OMIM 209850) are a collection of disorders that share the core symptom triad of limited or absent verbal communication, impaired social interactions, and restricted or repetitive behaviors and interests. There is a strong genetic component to autism and numerous loci have been linked to the disorder, some or all of which may contribute to the phenotype. The most common cytogenetic abnormality associated with autism is maternally derived duplication of chromosome 15q11-13 (Schanen 2006), a region that contains the $U B E 3 A$ gene linked to Angelman Syndrome as described above. These data raise the possibility that synaptic regulatory pathways similar to those implicated in AS could contribute to neural circuit dysfunction in autism. However, no single gene has been pinpointed as the cause of autism in the vast majority of cases.

Like RTT and AS, the symptoms of ASDs tend to appear during early postnatal life, suggesting the hypothesis that the disorder may arise as a result of disrupted synapse development or refinement (Bourgeron 2009). Indeed several of the loci that have been linked to autism in genetic studies are known to play important roles in synaptogenesis. Rare Mendelian transmission of autism has been linked to mutations in the neuroligins NLGN3 and NLGN4 (Jamain et al. 2003). Neuroligins form adhesive complexes across the synaptic cleft with members of the neurexin family (Ichtchenko et al. 1995) and have been suggested by genetic studies to regulate either the number (Chih et al. 2005) or the function of synapses
(Varoqueaux et al. 2006). One of the strongest genetic associations identified for ASDs is with the SHANK3 locus (Durand et al. 2007). Shank3 is a scaffolding protein that links together multiple components of glutamatergic synapses and is thought to be important for controlling the growth and maturation of excitatory synapses (Sheng and Kim 2000). Finally, a large genome-wide association study recently linked autism risk to single nucleotide polymorphisms near SEMA5A, which encodes an axon guidance molecule (Kantor et al. 2004; Weiss et al. 2009). Although the specific functions of semaphorin $5 \mathrm{~A}$ at $\mathrm{CNS}$ synapses remain to be determined, other members of the semaphorin family have been implicated in control of glutamatergic and/or GABAergic synapse numbers (Paradis et al. 2007).

Additional rare inherited autosomal recessive risk alleles for ASDs have been identified by mapping regions of homozygosity in families with shared ancestry (Morrow et al. 2008). A subset of the regions linked with autism risk contain large rare inherited deletions, suggesting they could be causative mutations. Interestingly, the three genes within or closest to the two largest deletions are target genes of activity-regulated transcription factors. These genes include the uncharacterized transcript C3orf58 and the protocadherin family member PCDH10, which are transcriptionally induced by membrane depolarization of cultured hippocampal neurons and are targets of regulation by MEF2 (Flavell et al. 2008). The third gene, NHE9 (SLC9A9) is a sodium-hydrogen exchanger localized to recycling endosomes that has also been linked to other neuropsychiatric disorders (de Silva et al. 2003; Markunas et al. 2010). Levels of NHE9 mRNA are not acutely altered in cultured hippocampal neurons by elevation of extracellular $\mathrm{KCl}$; however, this gene may be a target of transcriptional regulation by the activity-inducible transcription factor Npas4 (Lin et al. 2008). Although the functional consequences of the mutations identified in the study of Morrow et al. remain to be tested, these data raise the possibility that disruption of activity-regulated transcription may be a pathophysiological mechanism that 
A.E. West et al.

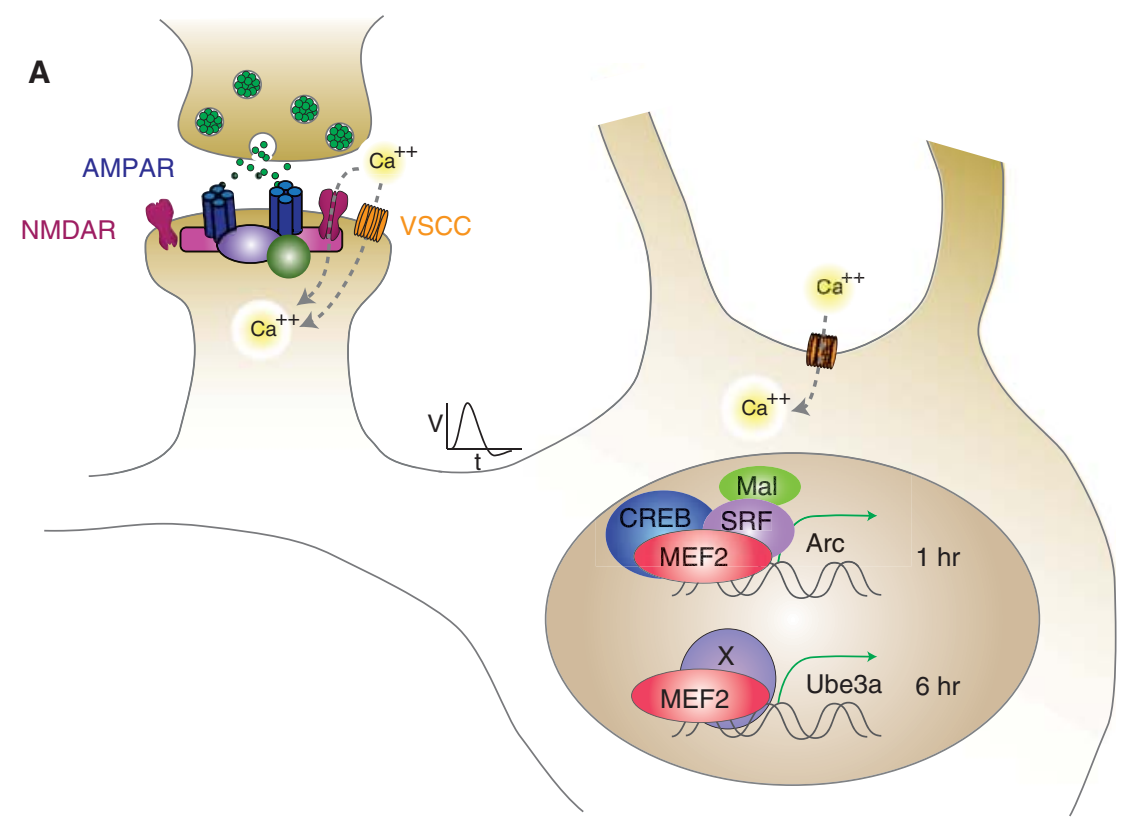

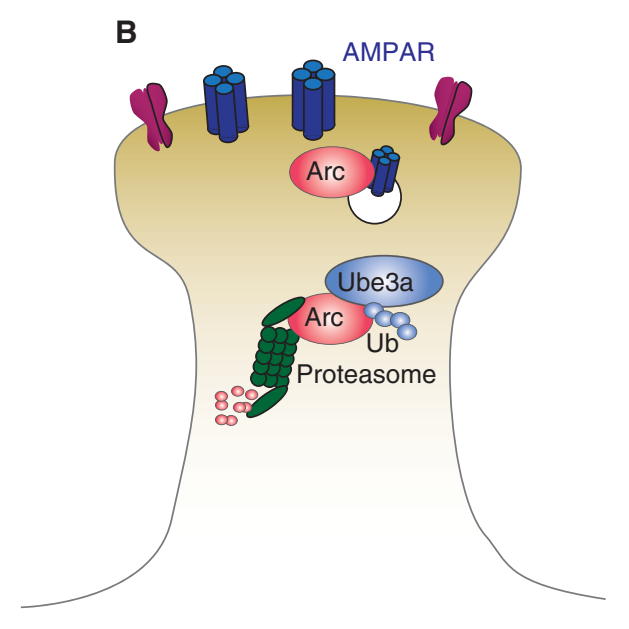

WT

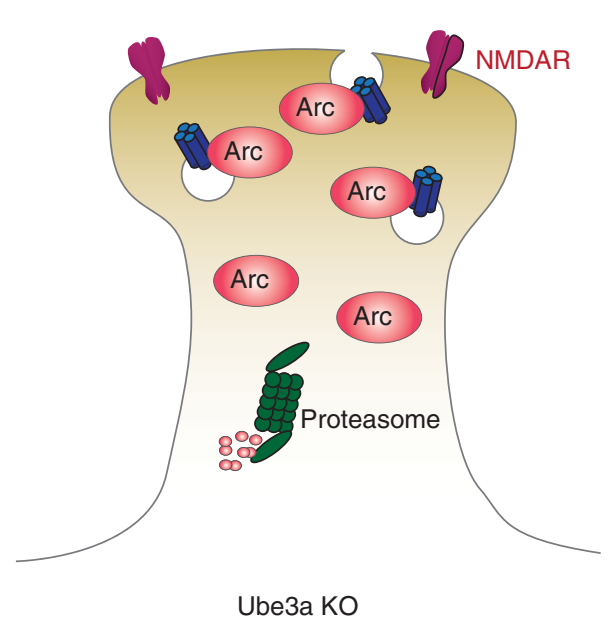

Ube3a KO

Figure 3. Ube3a/Arc-dependent dysregulation of activity-induced AMPA-type glutamate receptor trafficking in Angelman syndrome. (A) Synaptic activation of AMPA-type (AMPAR) and NMDA-type (NMDAR) glutamate receptors induces the rapid MEF2-dependent transcription of Arc and the slower MEF2-dependent transcription of Ube3a in the nucleus. Transcriptional regulation of Arc is initiated by calcium influx through both NMDARs and voltage-sensitive calcium channels (VSCCs). This plasma membrane signal is transmitted to the nucleus through the calcium-dependent activation of multiple intracellular signaling intermediates, including the MAP kinase cascade and actin signaling pathways that subsequently modulate nuclear transcription factor function. The Arc promoter is coregulated by multiple activity-responsive transcription factors including MEF2, CREB, SRF, and the SRF cofactor Mal. Other transcription factors that contribute to regulation of Ube3a remain to be identified (X). (B) At synapses, Arc protein contributes to endocytosis of AMPA-type glutamate receptors from the cell surface. In wild-type (WT) neurons, Arc levels are kept in check by Ube3Adependent proteosomal degradation. In Ube3a knockout neurons, elevated levels of Arc lead to abnormally high levels of AMPA-type glutamate receptor internalization, impairing synaptic strength. 


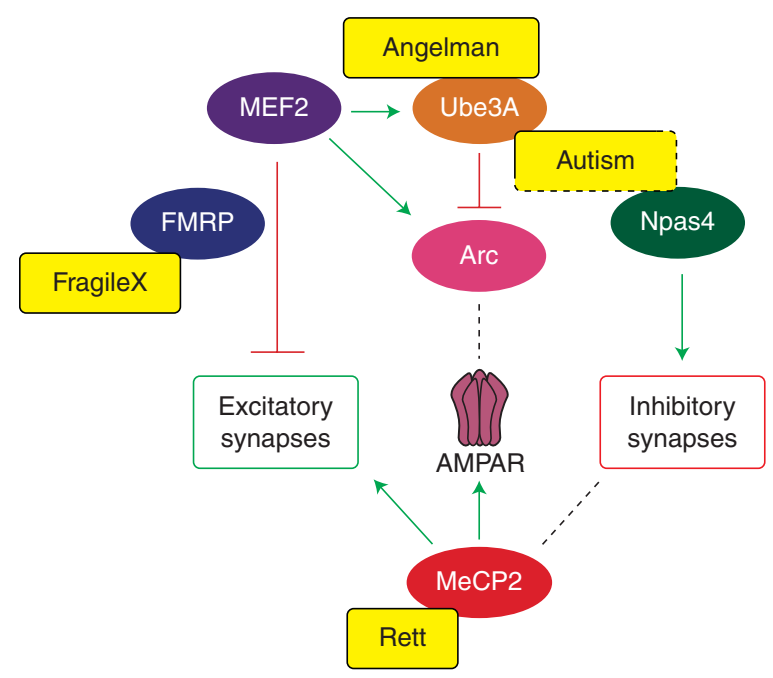

Figure 4. Model for a common activity-regulated transcriptional network underlying synapse dysfunction in neurodevelopmental diseases. The yellow boxes show four neurodevelopmental diseases associated with disrupted synapse development: Angelman syndrome, Fragile X syndrome (OMIM 300624), Rett syndrome, and autism. Each disease is shown next to a gene product implicated in disease pathogenesis. The dotted line around Autism depicts the hypothetical nature of the link between autism and Npas4 as discussed in the text. Green arrows show positive relationships between proteins or processes in the model; the red bars show inhibitory relationships. The dotted black lines indicate more complex relationships. For example Arc is implicated in endocytosis of AMPA-type glutamate receptors (AMPARs) from the plasma membrane, suggesting a negative relationship between these two proteins (Chowdhury et al. 2006); however, Arc is also required for some forms of LTP (McCurry et al. 2010), during which AMPARs are added to the synapse. The dotted line between MeCP2 and inhibitory synapses represents the observation that GABAergic synapse numbers are increased in some brain regions of Mecp2 mutant mice but decreased in others (Deng et al. 2010; Zhang et al. 2010). The ability of MEF2 overexpression to drive excitatory synapse elimination is impaired in mice lacking Fragile X mental retardation protein (FMRP) (Pfeiffer et al. 2010), suggesting a mechanistic link between the synaptic pathologies in Fragile X syndrome and the transcriptional pathways discussed here.

is common to genetically heterogeneous causes of autism.

\section{CONCLUSIONS}

A substantial body of evidence indicates that activity-regulated transcriptional networks are essential for the accurate development and maturation of synapses during postnatal life. Dysregulation of these transcriptional regulatory pathways has been associated with a number of neurodevelopmental diseases, suggesting that abnormalities of activity-regulated synapse development may be a common mechanism underlying neuropsychiatric and neurological impairments (Fig. 4). One of the striking findings is that some of these disorders appear to result in the brain being trapped in an immature state of synaptic development, such that later interventions that reawaken the developmental program may permit improved cognition. Thus, a further understanding of the signaling networks by which experience mediates synapse development may suggest new ideas for therapies for treating these disorders.

\section{ACKNOWLEDGMENTS}

We thank Janine Zieg for drawing the figures.

\section{REFERENCES}

Adams JP, Dudek SM. 2005. Late-phase long-term potentiation: Getting to the nucleus. Nat Rev Neurosci 6: 737-743.

Aizawa H, Hu SC, Bobb K, Balakrishnan K, Ince G, Gurevich I, Cowan M, Ghosh A. 2004. Dendrite development 
A.E. West et al.

regulated by CREST, a calcium-regulated transcriptional activator. Science 303: 197-202.

Alberti S, Krause SM, Kretz O, Philippar U, Lemberger T, Casanova E, Wiebel FF, Schwarz H, Frotscher M, Schutz G, et al. 2005. Neuronal migration in the murine rostral migratory stream requires serum response factor. Proc Natl Acad Sci 102: 6148-6153.

Amir RE, Van den Veyver IB, Wan M, Tran CQ, Francke U, Zoghbi HY. 1999. Rett syndrome is caused by mutations in X-linked MECP2, encoding methyl-CpG-binding protein 2. Nat Genet 23: 185-188.

Armstrong DD. 2005. Neuropathology of Rett syndrome. J Child Neurol 20: 747-753.

Bading H, Greenberg ME. 1991. Stimulation of protein tyrosine phosphorylation by NMDA receptor activation. Science 253: 912-914.

Bading H, Ginty DD, Greenberg ME. 1993. Regulation of gene expression in hippocampal neurons by distinct calcium signaling pathways. Science 260: 181-186.

Barbosa AC, Kim MS, Ertunc M, Adachi M, Nelson ED, McAnally J, Richardson JA, Kavalali ET, Monteggia LM, Bassel-Duby R, et al. 2008. MEF2C, a transcription factor that facilitates learning and memory by negative regulation of synapse numbers and function. Proc Natl Acad Sci 105: 9391-9396.

Barth AL, Gerkin RC, Dean KL. 2004. Alteration of neuronal firing properties after in vivo experience in a FosGFP transgenic mouse. J Neurosci 24: 6466-6475.

Belichenko NP, Belichenko PV, Mobley WC. 2009. Evidence for both neuronal cell autonomous and nonautonomous effects of methyl-CpG-binding protein 2 in the cerebral cortex of female mice with Mecp2 mutation. Neurobiol Dis 34: 71-77.

Bernstein BE, Meissner A, Lander ES. 2007. The mammalian epigenome. Cell 128: 669-681.

Berridge MJ. 1998. Neuronal calcium signaling. Neuron 21: $13-26$.

Bienvenu T, Chelly J. 2006. Molecular genetics of Rett syndrome: When DNA methylation goes unrecognized. Nat Rev Genet 7: 415-426.

Borodinsky LN, Root CM, Cronin JA, Sann SB, Gu X, Spitzer NC. 2004. Activity-dependent homeostatic specification of transmitter expression in embryonic neurons. Nature 429: 523-530.

Bourgeron T. 2009. A synaptic trek to autism. Curr Opin Neurobiol 19: 231-234.

Boyes J, Bird A. 1991. DNA methylation inhibits transcription indirectly via a methyl-CpG binding protein. Cell 64: $1123-1134$.

Burgoyne RD. 2007. Neuronal calcium sensor proteins: Generating diversity in neuronal $\mathrm{Ca}^{2+}$ signalling. Nat Rev Neurosci 8: 182-193.

Carrion AM, Link WA, Ledo F, Mellstrom B, Naranjo JR. 1999. DREAM is a $\mathrm{Ca}^{2+}$-regulated transcriptional repressor. Nature 398: $80-84$.

Chahrour M, Zoghbi HY. 2007. The story of Rett syndrome: From clinic to neurobiology. Neuron 56: 422-437.

Chahrour M, Jung SY, Shaw C, Zhou X, Wong ST, Qin J, Zoghbi HY. 2008. MeCP2, a key contributor to neurological disease, activates and represses transcription. Science 320: $1224-1229$.
Chang Q, Khare G, Dani V, Nelson S, Jaenisch R. 2006. The disease progression of Mecp2 mutant mice is affected by the level of BDNF expression. Neuron 49: 341-348.

Chang MC, Park JM, Pelkey KA, Grabenstatter HL, Xu D, Linden DJ, Sutula TP, McBain CJ, Worley PF. 2010. Narp regulates homeostatic scaling of excitatory synapses on parvalbumin-expressing interneurons. Nat Neurosci 13: 1090-1097.

Chao HT, Zoghbi HY, Rosenmund C. 2007. MeCP2 controls excitatory synaptic strength by regulating glutamatergic synapse number. Neuron 56: 58-65.

Chawla S, Vanhoutte P, Arnold FJ, Huang CL, Bading H. 2003. Neuronal activity-dependent nucleocytoplasmic shuttling of HDAC4 and HDAC5. J Neurochem 85: $151-159$.

Chen C, Regehr WG. 2000. Developmental remodeling of the retinogeniculate synapse. Neuron 28: 955-966.

Chen WG, Chang Q, Lin Y, Meissner A, West AE, Griffith EC, Jaenisch R, Greenberg ME. 2003. Derepression of BDNF transcription involves calcium-dependent phosphorylation of MeCP2. Science 302: 885-889.

Chih B, Engelman H, Scheiffele P. 2005. Control of excitatory and inhibitory synapse formation by neuroligins. Science 307.

Chowdhury S, Shepherd JD, Okuno H, Lyford G, Petralia RS, Plath N, Kuhl D, Huganir RL, Worley PF. 2006. Arc/Arg3.1 interacts with the endocytic machinery to regulate AMPA receptor trafficking. Neuron 52: 445-459.

Chrivia JC, Kwok RP, Lamb N, Hagiwara M, Montminy MR, Goodman RH. 1993. Phosphorylated CREB binds specifically to the nuclear protein CBP. Nature 365: 855-859.

Clapham DE. 2007. Calcium signaling. Cell 131: $1047-$ 1058.

Cline HT. 2001. Dendritic arbor development and synaptogenesis. Curr Op Neurobiol 11: 118-126.

Cline H, Haas K. 2008. The regulation of dendritic arbor development and plasticity by glutamatergic synaptic input: A review of the synaptotrophic hypothesis. J Physiol 586: $1509-1517$.

Cole AJ, Saffen DW, Baraban JM, Worley PF. 1989. Rapid increase of an immediate early gene messenger RNA in hippocampal neurons by synaptic NMDA receptor stimulation. Nature 340: 474-476.

Corriveau RA, Huh GS, Shatz CJ. 1998. Regulation of class I MHC gene expression in the developing and mature CNS by neural activity. Neuron 21: 505-520.

Crair MC, Gillespie DC, Stryker MP. 1998. The role of visual experience in the development of columns in cat visual cortex. Science 279: 566-570.

Crosio C, Cermakian N, Allis CD, Sassone-Corsi P. 2000. Light induces chromatin modification in cell of the mammalian circadian clock. Nat Neurosci 3: 1241-1247.

Crowley JC, Katz LC. 2000. Early development of ocular dominance columns. Science 290: 1321-1324.

Dani VS, Nelson SB. 2009. Intact long-term potentiation but reduced connectivity between neocortical layer 5 pyramidal neurons in a mouse model of Rett syndrome. J Neurosci 29: 11263-11270.

Dani VS, Chang Q, Maffei A, Turrigiano GG, Jaenisch R, Nelson SB. 2005. Reduced cortical activity due to a shift in the balance between excitation and inhibition in a 
mouse model of Rett syndrome. Proc Natl Acad Sci 102: 12560-12565.

de Silva MG, Elliott K, Dahl HH, Fitzpatrick E, Wilcox S, Delatycki M, Williamson R, Efron D, Lynch M, Forrest S. 2003. Disruption of a novel member of a sodium/ hydrogen exchanger family and DOCK3 is associated with an attention deficit hyperactivity disorder-like phenotype. J Med Genet 40: 733-740.

Deisseroth K, Bito H, Tsien RW. 1996. Signaling from synapse to nucleus: Postsynaptic CREB phosphorylation during multiple forms of hippocampal synaptic plasticity. Neuron 16: 89-101.

Deisseroth K, Mermelstein PG, Xia H, Tsien RW. 2003. Signaling from synapse to nucleus: the logic behind the mechanisms. Curr Opin Neurobiol 13: 354-365.

Deng JV, Rodriguiz RM, Hutchinson AN, Kim I-H, Wetsel WC, West AE. 2010. MeCP2 in the nucleus accumbens contributes to neural and behavioral responses to psychostimulants. Nat Neurosci 13: 1128-1136.

Dindot SV, Antalffy BA, Bhattacharjee MB, Beaudet AL 2008. The Angelman syndrome ubiquitin ligase localizes to the synapse and nucleus, and maternal deficiency results in abnormal dendritic spine morphology. Hum Mol Genet 17: 111-118.

Dolmetsch R. 2003. Excitation-transcription coupling: signaling by ion channels to the nucleus. Sci STKE 2003: PE4.

Dolmetsch RE, Pajvani U, Fife K, Spotts JM, Greenberg ME. 2001. Signaling to the nucleus by an L-type calcium channel-calmodulin complex through the MAP kinase pathway. Science 294: 333-339.

Durand CM, Betancur C, Boeckers TM, Bockmann J, Chaste P, Fauchereau F, Nygren G, Rastam M, Gillberg IC Anckarsater H, et al. 2007. Mutations in the gene encoding the synaptic scaffolding protein SHANK3 are associated with autism spectrum disorders. Nat Genet 39: 25-27.

Flavell SW, Cowan CW, Kim TK, Greer PL, Lin Y, Paradis S, Griffith EC, Hu LS, Chen C, Greenberg ME. 2006. Activity-dependent regulation of MEF2 transcription factors suppresses excitatory synapse number. Science 311: $1008-1012$

Flavell SW, Kim TK, Gray JM, Harmin DA, Hemberg M, Hong EJ, Markenscoff-Papadimitriou E, Bear DM, Greenberg ME. 2008. Genome-wide analysis of MEF2 transcriptional program reveals synaptic target genes and neuronal activity-dependent polyadenylation site selection. Neuron 60: 1022-1038.

Foeller E, Feldman DE. 2004. Synaptic basis for developmental plasticity in somatosensory cortex. Curr Opin Neurobiol 14: 89-95.

Fuks F, Hurd PJ, Wolf D, Nan X, Bird AP, Kourzarides T. 2003. The Methyl-CpG-binding protein MeCP2 links DNA methylation to histone methylation. J Biol Chem 278: 4035-4040.

Gaudilliere B, Konishi Y, de la Iglesia N, Yao G, Bonni A. 2004. A CaMKII-NeuroD signaling pathway specifies dendritic morphogenesis. Neuron 41: 229-241.

Ghosh A, Greenberg ME. 1995. Calcium signalling in neurons: Molecular mechanisms and cellular consequences. Science 268: 239-247.
Gomez TM, Robles E, Poo M, Spitzer NC. 2001. Filopodial calcium transients promote substrate-dependent growth cone turning. Science 291: 1983-1987.

Graef IA, Wang F, Charron F, Chen L, Neilson J, TessierLavigne M, Crabtree GR. 2003. Neurotrophins and netrins require calcineurin/NFAT signaling to stimulate outgrowth of embryonic axons. Cell 113: 657-670.

Graybiel AM, Moratalla R, Robertson HA. 1990. Amphetamine and cocaine induce drug-specific activation of the c-fos gene in striosome-matrix compartments and limbic subdivisions of the striatum. Proc Natl Acad Sci 87: 6912-6916.

Greenberg ME, Ziff EB. 1984. Stimulation of 3T3 cells induces transcription of the c-fos proto-oncogene. Nature 311: 433-437.

Greenberg ME, Greene LA, Ziff EB. 1985. Nerve growth factor and epidermal growth factor induce rapid transient changes in proto-oncogene transcription in $\mathrm{PC} 12$ cells. J Biol Chem 260: 14101-14110.

Greenberg ME, Ziff EB, Greene LA. 1986. Stimulation of neuronal acetylcholine receptors induces rapid gene transcription. Science 234: 80-83.

Greer PL, Greenberg ME. 2008. From synapse to nucleus: Calcium-dependent gene transcription in the control of synapse development and function. Neuron 59: 846-860.

Greer PL, Hanayama R, Bloodgood BL, Mardinly AR, Lipton DM, Flavell SW, Kim TK, Griffith EC, Waldon Z, Maehr R, et al. 2010. The Angelman Syndrome protein Ube3A regulates synapse development by ubiquitinating arc. Cell 140: 704-716.

Guan JS, Haggarty SJ, Giacometti E, Dannenberg JH, Joseph N, Gao J, Nieland TJ, Zhou Y, Wang X, Mazitschek R, et al. 2009. HDAC2 negatively regulates memory formation and synaptic plasticity. Nature 459.

Hanson MG, Landmesser LT. 2004. Normal patterns of spontaneous activity are required for correct motor axon guidance and the expression of specific guidance molecules. Neuron 43: 687-701.

Hardingham GE, Arnold FJ, Bading H. 2001. A calcium microdomain near NMDA receptors: on switch for ERK-dependent synapse-to-nucleus communication. Nat Neurosci 4: 565-566.

Hargreaves DC, Horng T, Medzhitov R. 2009. Control of inducible gene expression by signal-dependent transcriptional elongation. Cell 138: 129-145.

Henley J, Poo MM. 2004. Guiding neuronal growth cones using $\mathrm{Ca}^{2+}$ signals. Trends Cell Biol 14: 320-330.

Hensch TK. 2005. Critical period plasticity in local cortical circuits. Nat Rev Neurosci 6: 877-888.

Herdegen T, Leah JD. 1998. Inducible and constitutive transcription factors in the mamalian nervous system: Control of gene expression by Jun, Fos, and Krox, and CREB/ATF proteins. Brain Res Rev 28: 370-490.

Hill CS, Treisman R. 1999. Growth factors and gene expression: Fresh insights from arrays. Sci STKE 1999: PE1.

Hogan PG, Chen L, Nardone J, Rao A. 2003. Transcriptional regulation by calcium, calcineurin, and NFAT. Genes Dev 17: 2205-2232.

Hong EJ, McCord AE, Greenberg ME. 2008. A biological function for the neuronal activity-dependent component 
A.E. West et al.

of Bdnf transcription in the development of cortical inhibition. Neuron 60: 610-624.

Hong EJ, West AE, Greenberg ME. 2005. Transcriptional control of cognitive development. Curr Op Neurobiol 15: $21-28$.

Hooks BM, Chen C. 2006. Distinct roles for spontaneous and visual activity in remodeling of the retinogeniculate synapse. Neuron 52: 281-291.

Huang ZJ, Kirkwood A, Pizzorussi T, Porciatti V, Morales B, Bear MF, Maffei L, Tonegawa S. 1999. BDNF regulates the maturation of inhibition and the crtical period of plasticity in mouse visual cortex. Cell 98: 739-755.

Hubel DH. 1982. Exploration of the primary visual cortex, 1955-78. Nature 299: 515-524.

Hunt SP, Pini A, Evan G. 1987. Induction of c-fos-like protein in spinal cord neurons following sensory stimulation. Nature 328: 632-634.

Ichtchenko K, Hata Y, Nguyen T, Ullrich B, Missler M, Moomaw C, Sudhof TC. 1995. Neuroligin 1: A splice site-specific ligand for $\beta$-neurexins. Cell 81: 435-443.

Impey S, Davare M, Lasiek A, Fortin D, Ando H, Varlamova O, Obrietan K, Soderling TR, Goodman RH, Wayman GA. 2010. An activity-induced microRNA controls dendritic spine formation by regulating Rac1-PAK signaling. Mol Cell Neurosci 43: 146-156.

Jamain S, Quach H, Betancur C, Rastam M, Colineaux C, Gillberg IC, Soderstrom H, Giros B, Leboyer M, Gillberg C, et al. 2003. Mutations of the X-linked genes encoding neuroligins NLGN3 and NLGN4 are associated with autism. Nat Genet 34: 27-29.

Jiang YH, Armstrong D, Albrecht U, Atkins CM, Noebels JL, Eichele G, Sweatt JD, Beaudet AL. 1998b. Mutation of the Angelman ubiquitin ligase in mice causes increased cytoplasmic p53 and deficits of contextual learning and longterm potentiation. Neuron 21: 799-811.

Jiang Y, Tsai TF, Bressler J, Beaudet AL. 1998a. Imprinting in Angelman and Prader-Willi syndromes. Curr Op Gen Dev 8: $334-342$.

Jordan BA, Fernholz BD, Khatri L, Ziff EB. 2007. Activitydependent AIDA-1 nuclear signaling regulates nucleolar numbers and protein synthesis in neurons. Nat Neurosci 10: $427-435$.

Kandler K. 2004. Activity-dependent organization of inhibitory circuits: Lessons from the auditory system. Curr $O P$ Neurobiol 14: 96-104.

Kantor DB, Chivatakarn O, Peer KL, Oster SF, Inatani M, Hansen MJ, Flanagan JG, Yamaguchi Y, Sretavan DW, Giger RJ, et al. 2004. Semaphorin 5A is a bifunctional axon guidance cue regulated by heparan and chondroitin sulfate proteoglycans. Neuron 44: 961-975.

Kim TK, Hemberg M, Gray JM, Costa AM, Bear DM, Wu J, Harmin DA, Laptewicz M, Barbara-Haley K, Kuersten S, et al. 2010. Widespread transcription at neuronal activity-regulated enhancers. Nature 465: 182-187.

Kimura H, Shiota K. 2003. Methyl-CpG binding protein, $\mathrm{MeCP}$, is a target molecule for maintenance DNA methyltransferase, Dnmt1. J Biol Chem 278: 4806-4812.

Kline DD, Ogier M, Kunze DL, Katz DM. 2010. Exogenous brain-derived neurotrophic factor rescues synaptic dysfunction in Mecp2-null mice. J Neurosci 30: 5303-5310.
Klose RJ, Bird AP. 2006. Genomic DNA methylation: The mark and its mediators. Trends Biochem Sci 31: 89-97.

Knoll B, Nordheim A. 2009. Functional versatility of transcription factors in the nervous system: The SRF paradigm. Trends Neurosci 32: 432-442.

Knoll B, Kretz O, Fiedler C, Alberti S, Schutz G, Frotscher M, Nordheim A. 2006. Serum response factor controls neuronal circuit assembly in the hippocampus. Nat Neurosci 9: 195-204.

Kohara K, Yasuda H, Huang Y, Adachi N, Sohya K, Tsumoto T. 2007. A local reduction in cortical GABAergic synapses after a loss of endogenous brain-derived neurotrophic factor, as revealed by single-cell gene knock-out method. J Neurosci 27: 7234-7244.

Kokobu M, Nishio M, Ribar TJ, Anderson KA, West AE, Means AR. 2009. BDNF-mediated cerebellar granule cell development is impaired in mice null for CaMKK2 or CaMKIV. J Neurosci 29: 8901-8913.

Kumar A, Choi KH, Renthal W, Tsankova NM, Theobald DE, Truong HT, Russo SJ, Laplant Q, Sasaki TS, Whistler $\mathrm{KN}$, et al. 2005. Chromatin remodeling is a key mechanism underlying cocaine-induced plasticity in striatum. Neuron 48: 303-314.

Lamb NJ, Fernandez A, Tourkine N, Jeanteur P, Blanchard JM. 1990. Demonstration in living cells of an intragenic negative regulatory element within the rodent c-fos gene. Cell 61: 485-496.

Lanahan A, Worley P. 1998. Immediate-early genes and synaptic function. Neurobiol Learn Mem 70: 37-43.

Lerea LS, McNamara JO. 1993. Ionotropic glutamate receptor subtypes activate c-fos transcription by distinct calcium-requiring intracellular signaling pathways. Neuron 10: 31-41.

Levitt P, Eagleson KL, Powell EM. 2004. Regulation of neocortical interneuron development and the implications for neurodevelopmental disorders. Trends Neurosci 27: 400-406.

Lin Y, Bloodgood BL, Hauser JL, Lapan AD, Koon AC, Kim TK, Hu LS, Malik AN, Greenberg ME. 2008. Activitydependent regulation of inhibitory synapse development by Npas4. Nature 455: 1198-1204.

Lohmann C, Bonhoeffer T. 2008. A role for local calcium signaling in rapid synaptic partner selection by dendritic filopodia. Neuron 59: 253-260.

Lyford G, Yamagata K, Kaufmann W, Barnes C, Sanders L, Copeland N, Gilbert D, Jenkins N, Lanahan A, Worley P. 1995. Arc, a growth factor and activity-regulated gene, encodes a novel cytoskeleon-associated protein that is enriched in neuronal dendrites. Neuron 14: $433-445$.

Ma DK, Jang MH, Guo JU, Kitabatake Y, Chang ML, Pow-Anpongkul N, Flavell RA, Lu B, Ming GL, Song H. 2009. Neuronal activity-induced Gadd45b promotes epigenetic DNA demethylation and adult neurogenesis. Science 323: 1074-1077.

Majdan M, Shatz CJ. 2006. Effects of visual experience on activity-dependent gene regulation in cortex. Nat Neurosci 9: 650-659.

Mann EO, Paulsen O. 2007. Role of GABAergic inhibition in hippocampal network oscillations. Trends Neurosci 30: 343-349. 
Marais R, Wynne J, Treisman R. 1993. The SRF accessory protein Elk-1 contains a growth factor-regulated transcriptional activation domain. Cell 73: 381-393.

Marie H, Morishita W, Yu X, Calakos N, Malenka RC. 2005. Generation of silent synapses by acute in vivo expression of CaMKIV and CREB. Neuron 45: 741-752.

Markunas CA, Quinn KS, Collins AL, Garrett ME, Lachiewicz AM, Sommer JL, Morrissey-Kane E, Kollins SH, Anastopoulos AD, Ashley-Koch AE. 2010. Genetic variants in SLC9A9 are associated with measures of attention-deficit/hyperactivity disorder symptoms in families. Psychiatr Genet 20: 73-81.

Matsuura T, Sutcliffe JS, Fang P, Galjaard RJ, Jiang YH, Benton CS, Rommens JM, Beaudet AL. 1997. De novo truncating mutations in E6-AP ubiquitin-protein ligase gene (UBE3A) in Angelman syndrome. Nat Genet 15: 74-77.

McCurry CL, Shepherd JD, Tropea D, Wang KH, Bear MF, Sur M. 2010. Loss of Arc renders the visual cortex impervious to the effects of sensory experience or deprivation. Nat Neurosci 13: 450-457.

McDowell KA, Hutchinson AN, Wong-Goodrich SJE, Presby MM, Su D, Rodriguiz RM, Law KC, Williams CL, Wetsel WC, West AE. 2010. Reduced cortical BDNF expression and aberrant memory in Carf knockout mice. J Neurosci 30: 7453-7465.

Medrihan L, Tantalaki E, Aramuni G, Sargsyan V, Dudanova I, Missler M, Zhang W. 2008. Early defects of GABAergic synapses in the brain stem of a MeCP2 mouse model of Rett syndrome. J Neurophysiol 99: 112-121.

Meffert MK, Chang JM, Wiltgen BJ, Fanselow MS, Baltimore D. 2003. NF-kappa B functions in synaptic signaling and behavior. Nat Neurosci 6: 1072-1078.

Misgeld T, Burgess RW, Lewis RM, Cunningham JM, Lichtman JW, Sanes JR. 2002. Roles of neurotransmitter in synapse formation: Development of neuromuscular junctions lacking choline acetyltransferase. Neuron 36: 635-648.

Morales B, Choi SY, Kirkwood A. 2002. Dark rearing alters the development of GABAergic transmission in visual cortex. J Neurosci 22: 8084-8090.

Morgan JI, Curran T. 1986. Role of ion flux in the control of c-fos expression. Nature 322: 552-555.

Morgan JI, Cohen DR, Hempstead JL, Curran T. 1987. Mapping patterns of c-fos expression in the central nervous system after seizure. Science 237: 192-197.

Morrow EM, Yoo SY, Flavell SW, Kim TK, Lin Y, Hill RS, Mukaddes NM, Balkhy S, Gascon G, Hashmi A, et al. 2008. Identifying autism loci and genes by tracing recent shared ancestry. Science 321: 218-223.

Murphy DD, Segal M. 1997. Morphological plasticity of dendritic spines in central neurons is mediated by activation of cAMP response element binding protein. Proc Natl Acad Sci 94: 1482-1487.

Murphy TH, Worley PF, Baraban JM. 1991. L-type voltagesensitive calcium channels mediate synaptic activation of immediate early genes. Neuron 7: 625-635.

Nan X, Ng HH, Johnson CA, Laherty CD, Turner BM, Eisenman RN, Bird A. 1998. Transcriptional repression by the methyl-CpG-binding protein MeCP2 involves a histone deacetylase complex. Nature 393: 386-389.
Nedivi E, Wu G-Y, Cline HT. 1998. Promotion of dendritic growth by CPG15, an activity-induced signaling molecule. Science 281: 1863-1866.

Nelson ED, Kavalali ET, Monteggia LM. 2006. MeCP2dependent transcriptional repression regulates excitatory neurotransmission. Curr Biol 16: 710-716.

Niell CM, Meyer MP, Smith SJ. 2004. In vivo imaging of synapse formation on a growing dendritic arbor. Nat Neurosci 7: 254-260.

O’Brien RJ, Xu D, Petralia RS, Steward O, Huganir RL, Worley P. 1999. Synaptic clustering of AMPA receptors by the extracellular immediate-early gene product Narp. Neuron 23: 309-323.

Ogier M, Wang H, Hong E, Wang Q, Greenberg ME, Katz DM. 2007. Brain-derived neurotrophic factor expression and respiratory function improve after ampakine treatment in a mouse model of Rett syndrome. J Neurosci 27: 10912-10917.

Paradis S, Harrar DB, Lin Y, Koon AC, Hauser JL, Griffith EC, Zhu L, Brass LF, Chen C, Greenberg ME. 2007. An RNAi-based approach identifies molecules required for glutamatergic and GABAergic synapse development. Neuron 53: 217-232.

Pfeiffenberger C, Cutforth T, Woods G, Yamada J, Renteria RC, Copenhagen DR, Flanagan JG, Feldheim DA. 2005. Ephrin-As and neural activity are required for eyespecific patterning during retinogeniculate mapping. Nat Neurosci 8: 1022-1027.

Pfeiffer BE, Zang T, Wilkerson JR, Taniguchi M, Maksimova MA, Smith LN, Cowan CW, Huber KM. 2010. Fragile X mental retardation protein is required for synapse elimination by the activity-dependent transcription factor MEF2. Neuron 66: 191-197.

Polleux F, Ince-Dunn G, Ghosh A. 2007. Transcriptional regulation of vertebrate axon guidance and synapse formation. Nat Rev Neurosci 8: 331-340.

Poo M-m. 2001. Neurotrophins as synaptic modulators. Nat Rev Neurosci 2: 24-32.

Purves D, Lichtman JW. 1980. Elimination of synapses in the developing nervous system. Science 210: 153-157.

Qiu Z, Ghosh A. 2008. A calcium-dependent switch in a CREST-BRG1 complex regulates activity-dependent gene expression. Neuron 60: 775-787.

Rabacchi S, Bailly Y, Delhaye-Bouchaud N, Mariani J. 1992. Involvement of the $N$-methyl $D$-aspartate (NMDA) receptor in synapse elimination during cerebellar development. Science 256: 1823-1825.

Rajan I, Cline HT. 1998. Glutamate receptor activity is required for normal development of tectal cell dendrites in vivo. J Neurosci 18: 7836-7846.

Rakic P, Bourgeois JP, Eckenhoff MF, Zecevic N, GoldmanRakic PS. 1986. Concurrent overproduction of synapses in diverse regions of the primate cerebral cortex. Science 232: $232-235$.

Redmond L, Ghosh A. 2005. Regulation of dendritic development by calcium signaling. Cell Calcium 37: 411-416.

Redmond L, Kashani AH, Ghosh A. 2002. Calcium regulation of dendritic growth via CaM kinase IV and CREBmediated transcription. Neuron 34: 999-1010. 


\section{A.E. West et al.}

Rial Verde EM, Lee-Osbourne J, Worley PF, Malinow R, Cline HT. 2006. Increased expression of the immediateearly gene arc/arg3.1 reduces AMPA receptor-mediated synaptic transmission. Neuron 52: 461-474.

Roh TY, Cuddapah S, Zhao K. 2005. Active chromatin domains are defined by acetylation islands revealed by genome-wide mapping. Genes Dev 19: 542-552.

Rosen LB, Ginty DD, Weber MJ, Greenberg ME. 1994. Membrane depolarization and calcium influx stimulate MEK and MAP kinase via activation of Ras. Neuron 12: 1207-1221.

Rubenstein JL, Merzenich MM. 2003. Model of autism Increased ratio of excitation/inhibition in key neural systems. Genes Brain Behav 2: 255-267.

Ryser S, Fujita T, Tortola S, Piuz I, Schlegel W. 2007. The rate of c-fos transcription in vivo is continuously regulated at the level of elongation by dynamic stimulus-coupled recruitment of positive transcription elongation factor b. J Biol Chem 282: 5075-5084.

Sabatini BL, Maravall M, Svoboda K. 2001. $\mathrm{Ca}^{2+}$ signaling in dendritic spines. Curr Opin Neurobiol 11: 349-356.

Sakata K, Woo NH, Martinowich K, Greene JS, Schloesser RJ, Shen L, Lu B. 2009. Critical role of promoter IV-driven BDNF transcription in GABAergic transmission and synaptic plasticity in the prefrontal cortex. Proc Natl Acad Sci 106: 5942-5947.

Sala C, Futai K, Yamamoto K, Worley PF, Hayashi Y, Sheng M. 2003. Inhibition of dendritic spine morphogenesis and synaptic transmission by activity-inducible protein Homerla. J Neurosci 23: 6327-6337.

Sanes JR, Lichtman JW. 2001. Induction, assembly, maturation and maintenance of a postsynaptic apparatus. Nat Rev Neurosci 2: 791-805.

Sato M, Stryker MP. 2010. Genomic imprinting of experience-dependent cortical plasticity by the ubiquitin ligase gene Ube3a. Proc Natl Acad Sci 107: 5611-5616.

Schanen NC. 2006. Epigenetics of autism spectrum disorders. Hum Mol Genet 15 Spec No 2: R138-R150.

Schwartz N, Schohl A, Ruthazer ES. 2009. Neural activity regulates synaptic properties and dendritic structure in vivo through calcineurin/NFAT signaling. Neuron 62: 655-669.

Shalizi A, Gaudilliere B, Yuan Z, Stegmuller J, Shirogane T, Ge Q, Tan Y, Schulman B, Harper JW, Bonni A. 2006. A calcium-regulated MEF2 sumoylation switch controls postsynaptic differentiation. Science 311: 1012-1017.

Sheng M, Greenberg ME. 1990. The regulation and function of c-fos and other immediate early genes in the nervous system. Neuron 4: 477-485.

Sheng M, Kim E. 2000. The Shank family of scaffold proteins. J Cell Sci 113: 1851-1856.

Sheng M, Thompson MA, Greenberg ME. 1991. CREB: A $\mathrm{Ca}^{2+}$-regulated transcription factor phosphorylated by calmodulin-dependent kinases. Science 252: 1427-1430.

Shepherd JD, Rumbaugh G, Wu J, Chowdhury S, Plath N, Kuhl D, Huganir RL, Worley PF. 2006. Arc/Arg3.1 mediates homeostatic synaptic scaling of AMPA receptors. Neuron 52: 475-484.

Sherin JE, Shiromani PJ, McCarley RW, Saper CB. 1996. Activation of ventrolateral preoptic neurons during sleep. Science 271: 216-219.
Shrum CK, Defrancisco D, Meffert MK. 2009. Stimulated nuclear translocation of NF-kappaB and shuttling differentially depend on dynein and the dynactin complex. Proc Natl Acad Sci 106: 2647-2652.

Skene PJ, Illingworth RS, Webb S, Kerr AR, James KD, Turner DJ, Andrews R, Bird AP. 2010. Neuronal MeCP2 is expressed at near histone-octamer levels and globally alters the chromatin state. Mol Cell 37: 457-468.

Spitzer NC. 2006. Electrical activity in early neuronal development. Nature 444: 707-712.

Strahl BD, Allis CD. 2000. The language of covalent histone modifications. Nature 403: 41-45.

Suzuki S, Zhou H, Neumaier JF, Pham TA. 2007. Opposing functions of CREB and MKK1 synergistically regulate the geometry of dendritic spines in visual cortex. J Comp Neurol 503: 605-617.

Tagawa Y, Kanold PO, Majdan M, Shatz CJ. 2005. Multiple periods of functional ocular dominance plasticity in mouse visual cortex. Nat Neurosci 8: 380-388.

Takasu MA, Dalva MB, Zigmond RE, Greenberg ME. 2002. Modulation of NMDA receptor-dependent calcium influx and gene expression through $\mathrm{EphB}$ receptors. Science 295: 491-495.

Tao X, West AE, Chen WG, Corfas G, Greenberg ME. 2002. A calcium-responsive transcription factor, CaRF, that regulates neuronal activity-dependent expression of BDNF. Neuron 33: 383-395.

Tropea D, Giacometti E, Wilson NR, Beard C, McCurry C, Fu DD, Flannery R, Jaenisch R, Sur M. 2009. Partial reversal of Rett Syndrome-like symptoms in MeCP2 mutant mice. Proc Natl Acad Sci 106: 2029-2034.

Tropea D, Kreiman G, Lyckman A, Mukherjee S, Yu H, Horng S, Sur M. 2006. Gene expression changes and molecular pathways mediating activity-dependent plasticity in visual cortex. Nat Neurosci 9: 660-668.

Tsankova NM, Kumar A, Nestler EJ. 2004. Histone modifications at gene promoter regions in rat hippocampus after acute and chronic electroconvulsive seizures. J Neurosci 24: 5603-5610.

Tudor M, Akbarian S, Chen RZ, Jaenisch R. 2002. Transcriptional profiling of a mouse model for Rett syndrome reveals subtle transcriptional changes in the brain. Proc Natl Acad Sci 99: 15536-15541.

Turrigiano GG, Nelson SB. 2004. Homeostatic plasticity in the developing nervous system. Nat Rev Neurosci 5: 97-107.

Tzingounis AV, Nicoll RA. 2006. Arc/Arg3.1: Linking gene expression to synaptic plasticity and memory. Neuron 52: 403-407.

Van den Heuvel DM, Pasterkamp RJ. 2008. Getting connected in the dopamine system. Prog Neurobiol 85: 75-93.

Varoqueaux F, Aramuni G, Rawson RL, Mohrmann R, Missler M, Gottmann K, Zhang W, Sudhof TC, Brose N. 2006 Neuroligins determine synapse maturation and function. Neuron 51: 741-754.

Velho TA, Pinaud R, Rodrigues PV, Mello CV. 2005. Co-induction of activity-dependent genes in songbirds. Eur J Neurosci 22.

Volpe JJ. 2008. Neurology of the newborn, pp. 45-102. W.B. Saunders, Philadelphia. 
Wang H, Chan SA, Ogier M, Hellard D, Wang Q, Smith C, Katz DM. 2006. Dysregulation of brain-derived neurotrophic factor expression and neurosecretory function in Mecp2 null mice. J Neurosci 26: 10911-10915.

Wayman GA, Davare M, Ando H, Fortin D, Varlamova O, Cheng HY, Marks D, Obrietan K, Soderling TR, Goodman RH, et al. 2008a. An activity-regulated microRNA controls dendritic plasticity by down-regulating p250GAP. Proc Natl Acad Sci 105: 9093-9098.

Wayman GA, Impey S, Marks D, Saneyoshi T, Grant WF, Derkach V, Soderling TR. 2006. Activity-dependent dendritic arborization mediated by CaM-kinase I activation and enhanced CREB-dependent transcription of Wnt-2. Neuron 50: 897-909.

Wayman GA, Lee YS, Tokumitsu H, Silva A, Soderling TR 2008b. Calmodulin-kinases: Modulators of neuronal development and plasticity. Neuron 59: 914-931.

Weiss LA, Arking DE, Daly MJ, Chakravarti A. 2009. A genome-wide linkage and association scan reveals novel loci for autism. Nature 461: 802-808.

West AE, Griffith EC, Greenberg ME. 2002. Regulation of transcription factors by neuronal activity. Nat Rev Neurosci 3: 921-931.

Wickramasinghe SR, Alvania RS, Ramanan N, Wood JN Mandai K, Ginty DD. 2008. Serum response factor mediates NGF-dependent target innervation by embryonic DRG sensory neurons. Neuron 58: 532-545.

Wiesel TN. 1982. Postnatal development of the visual cortex and the influence of environment. Nature 299: 583-591.

Wolffe AP, Khochbin S, Dimitrov S. 1997. What do linker histones do in chromatin? Bioessays 19: 249-255.

Wood L, Gray NW, Zhou Z, Greenberg ME, Shepherd GM. 2009. Synaptic circuit abnormalities of motor-frontal layer $2 / 3$ pyramidal neurons in an RNA interference model of methyl-CpG-binding protein 2 deficiency. $J$ Neurosci 29: 12440-12448.

Wu JI, Lessard J, Olave IA, Qiu Z, Ghosh A, Graef IA, Crabtree GR. 2007. Regulation of dendritic development by
Activity-Regulated Transcription and Synapses

neuron-specific chromatin remodeling complexes. Neuron 56: 94-108.

Xia Z, Dudek H, Miranti CK, Greenberg ME. 1996. Calcium influx via the NMDA receptor induces immediate early gene transcription by a MAP kinase/ERK-dependent mechanism. J Neurosci 16: 5425-5436.

Xiao B, Tu JC, Worley PF. 2000. Homer: a link between neural activity and glutamate receptor function. Curr Opin Neurobiol 10: 370-374.

Yashiro K, Riday TT, Condon KH, Roberts AC, Bernardo DR, Prakash R, Weinberg RJ, Ehlers MD, Philpot BD. 2009. Ube3a is required for experience-dependent maturation of the neocortex. Nat Neurosci 12: 777-783.

Yi JJ, Ehlers MD. 2005. Ubiquitin and protein turnover in synapse function. Neuron 47: 629-632.

Yoo AS, Staahl BT, Chen L, Crabtree GR. 2009. MicroRNAmediated switching of chromatin-remodelling complexes in neural development. Nature 460: 642-646.

Zhang ZW, Zak JD, Liu H. 2010. MeCP2 is required for normal development of GABAergic circuits in the thalamus. J Neurophysiol 103: 2470-2481.

Zhang SJ, Steijaert MN, Lau D, Schutz G, Delucinge-Vivier C, Descombes P, Bading H. 2007. Decoding NMDA receptor signaling: Identification of genomic programs specifying neuronal survival and death. Neuron 53: 549-562.

Zhang SJ, Zou M, Lu L, Lau D, Ditzel DA, Delucinge-Vivier C, Aso Y, Descombes P, Bading H. 2009. Nuclear calcium signaling controls expression of a large gene pool: Identification of a gene program for acquired neuroprotection induced by synaptic activity. PLoS Genet 5: e1000604.

Zhou Z, Hong EJ, Cohen S, Zhao WN, Ho HY, Schmidt L, Chen WG, Lin Y, Savner E, Griffith EC, et al. 2006. Brain-specific phosphorylation of $\mathrm{MeCP} 2$ regulates activity-dependent $B d n f$ transcription, dendritic growth, and spine maturation. Neuron 52: 255-269. 


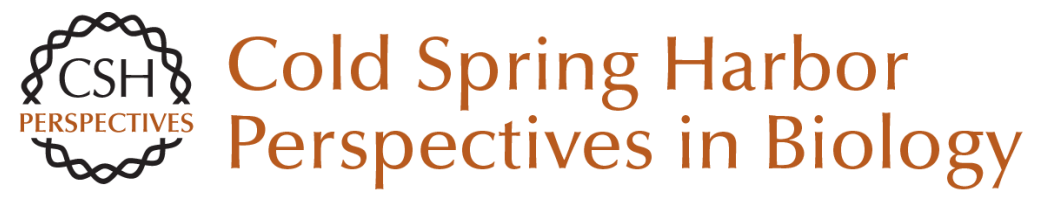

\title{
Neuronal Activity-Regulated Gene Transcription in Synapse Development and Cognitive Function
}

\author{
Anne E. West and Michael E. Greenberg
}

Cold Spring Harb Perspect Biol 2011; doi: 10.1101/cshperspect.a005744 originally published online May 9, 2011

\section{Subject Collection The Synapse}

\section{Studying Signal Transduction in Single Dendritic \\ Spines \\ Ryohei Yasuda}

Synaptic Vesicle Pools and Dynamics

AbdulRasheed A. Alabi and Richard W. Tsien

Synapses and Memory Storage

Mark Mayford, Steven A. Siegelbaum and Eric R. Kandel

Synapses and Alzheimer's Disease

Morgan Sheng, Bernardo L. Sabatini and Thomas C. Südhof

Synaptic Cell Adhesion

Markus Missler, Thomas C. Südhof and Thomas Biederer

Synaptic Dysfunction in Neurodevelopmental

Disorders Associated with Autism and Intellectual

Disabilities

Huda Y. Zoghbi and Mark F. Bear

The Postsynaptic Organization of Synapses Morgan Sheng and Eunjoon Kim

Presynaptic LTP and LTD of Excitatory and Inhibitory Synapses

Pablo E. Castillo
Synaptic Vesicle Endocytosis

Yasunori Saheki and Pietro De Camilli

Short-Term Presynaptic Plasticity Wade G. Regehr

NMDA Receptor-Dependent Long-Term

Potentiation and Long-Term Depression

(LTP/LTD)

Christian Lüscher and Robert C. Malenka

Ultrastructure of Synapses in the Mammalian

Brain

Kristen M. Harris and Richard J. Weinberg

Calcium Signaling in Dendritic Spines

Michael J. Higley and Bernardo L. Sabatini

Synaptic Neurotransmitter-Gated Receptors

Trevor G. Smart and Pierre Paoletti

Synaptic Vesicle Exocytosis

Thomas C. Südhof and Josep Rizo

Vesicular and Plasma Membrane Transporters for

Neurotransmitters

Randy D. Blakely and Robert H. Edwards

For additional articles in this collection, see http://cshperspectives.cshlp.org/cgi/collection/

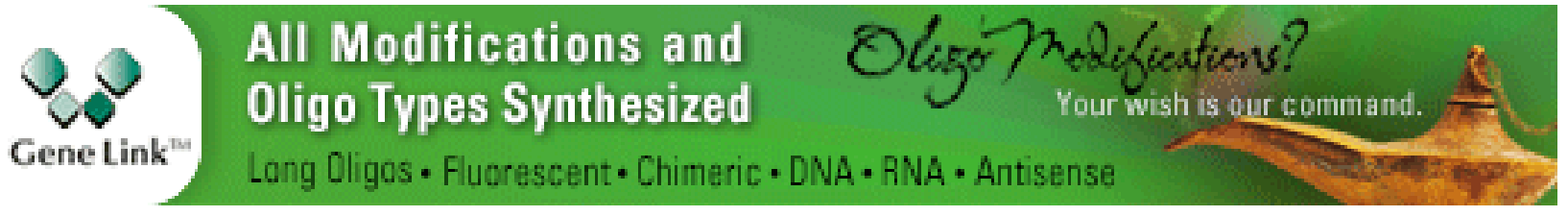

Copyright @ 2011 Cold Spring Harbor Laboratory Press; all rights reserved 